\title{
A stylistic analysis of Henry Fielding's Tom Jones: a socio-pragmatic view
}

\author{
Hosni Mostafa El-dali (i) ${ }^{1 凶}$
}

The purpose of this study is three fold; first, it attempts to show to what extent Fielding's writings unfold the basic characteristics of the eighteenth century lines of thinking, foremost of which is the importance of context for the determination of meaning. Second, it attempts to show Fielding's philosophy of human nature which, according to him, is a mixture of man's selfishness, greediness, honesty and charity, all of which are characteristics of the 'characters' nature. Third, the present study sheds some light on Fielding's technique in writing. The importance of introducing ironic techniques is to stimulate the reader's mental imagination to understand opposite meanings and in consequence adopt a proper evaluation of the character's behaviour. Fielding discusses through irony some important concepts such as chastity, reason and gentility, yet no direct clue is given to the readers to give a precise interpretation about them. It is also through irony that the interpretation of these concepts are hindered by perplexing assumptions as connotations of meaning make it difficult for the readers to give any judgment or adopt any evaluation. The study shows that Fielding's technique in 'Tom Jones' is incorporated within a third omniscience narrative, which gives the narrator the chance to preside over his creation and commenting on certain attitudes and actions. It concludes that the mark of shame bestowed by earlier critics on Fielding as intrusive narrator is eliminated on the grounds that his presence within the text is directed for teaching purposes.

\footnotetext{
${ }^{1}$ Department of Cognitive Sciences, College of Humanities and social Sciences, United Arab Emirates University, Al Ain, United Arab Emirates.

凶email: hasan.mostafa@uaeu.ac.ae
} 


\section{Introduction}

pplying linguistics to the study of literature has been evolving an increasing desire for investigation and evaluation. The study of literature implies the evaluation of style, and style itself works as an intermediary between language and literature. The present study is a stylistic analysis of language use and characterization in Henry Fielding's Tom Jones from a socio-pragmatic perspective. It claims that a close-reading of the work based on a socio-pragmatic perspective can help illuminate intriguing aspects of Fielding's novel and its relationship with its intellectual context; the role of contextualization in the creation of meaning; the idea that ideal character is of a mixed nature, and the use of satire and irony as main features of Fielding's style, though which he attempts to capture the dual understanding of 'charity', chastity', and 'benevolence'. Some points have already been discussed by many critics such as the picaresque features in Fielding's literary work and his narrative omniscient point of view, the God-like narrator and the role of the reader (see Alter, 1964; Apostoli, 2004; Ardila, 2010, 2015; Claude, 2007; Eisenberg, 2018; Jakubjakova, 2017; Mancing, 2015; Wicks, 2002; Birke, 2015; Iser, 1978; O’Halloran, 2007).

\section{The purpose}

The present study, first, attempts to show to what extent Fielding's writings unfold the basic characteristics of the eighteenthcentury lines of thinking, foremost of which is the importance of context for the determination of meaning. Fielding's concern is mostly directed to the flexibility of language, to ways of making the mind more flexible and capable of drawing shades of meaning. Second, it attempts to show Fielding's philosophy of human nature, which, according to him, is a mixture of man's selfishness, greediness, honesty and charity, all of which are characteristics of the 'characters' nature. Fielding's target is to expound that vice contradicts virtue and that there is no way for evil to prevail, thus it is the latter which ultimately triumphs over the former. In addition, the present study sheds some light on Fielding's technique in writing. The importance of introducing ironic techniques is to stimulate the reader's mental imagination to understand opposite meanings and in consequence adopt a proper evaluation of the character's behaviour. Fielding discusses through irony some important concepts, namely, chastity, reason and gentility, yet no direct clue is given to the readers to give a precise interpretation about them. It is through irony that interpretations of these concepts are hindered by perplexing assumptions as connotations of meaning make it difficult for the readers to give any judgment or adopt any evaluation.

\section{Organization of the study}

The present study consists of six interrelated sections as follows: (1) Introduction/the purpose; (2) methodological background; (3) literature review, which covers four pertinent issues. Section "Discourse: Three approaches to discourse analysis" presents a review of the term 'discourse' and the three approaches in discourse analysis. Section "Language, linguistics, and literature" examines the relationship between language, linguistics and literature. Section "Stylistics and literary studies" examines the relationship between stylistics and literary studies, and section "Controversial views of Henry Fielding" deals with the controversial views of Henry Fielding. Section "Discussion" consists of four sub-sections. Section "Fielding's narrative technique" deals with Fielding's narrative technique', section "Henry Fielding and the technique of irony in Tom Jones" deals with Fielding's technique of irony in Tom Jones, section "Fielding's characters in Tom Jones" deals with Fielding's characters in Tom Jones, with special reference to the two concepts of 'chastity' and 'charity'; section "A political reading of Tom Jones: Fielding as a political operative" presents a political reading of Tom Jones and Fielding as a political operative, which is mainly based on Hume (2010); section "Conclusion" presents the conclusions of the study and, section "Bibliography" presents the references of the study.

\section{Methodological background}

According to Mcintyre (2012, pp. 1-2), "it is a good idea to start [our analysis] with [our] initial thoughts and feelings about the text [we] are going to analyse. Then when we do the actual analysis, we can see if we were right or wrong in our initial interpretation. The linguistic structure of the text, sometimes, does not support our interpretation, in which case we may have to reconsider this in the light of our analysis. This is why stylistics is useful as a method of interpreting texts". The stylistic analysis carried out in the present study is embedded within a framework of critical discourse analysis (CDA), as will be clarified later.

The present study uses the content analysis technique. Content analysis is a highly flexible research method that has been widely used. It is applied in qualitative, quantitative, and sometimes mixed modes of research frameworks and employs a wide range of analytical techniques. As a research methodology, it has its roots in the study of mass communication in the 1950s (Berelson, 1952; Busha and Harter, 1980; de Sola Pool, 1959; Krippendorff, 2004). Since then, researchers in many fields have used content analysis and, in the process, they have adapted content analysis to suit the unique needs of their research questions. They, also, have developed a cluster of techniques and approaches for analysing texts grouped under the broad term of textual analysis. As defined by Krippendorff (2004, p. 18), content analysis is a research technique for making replicable and valid differences from texts (or other meaningful matter) to the contexts of their use. Such a definition emphasizes the fact that the notion of inference is especially important in content analysis.

The present study uses qualitative content analysis (QCA) as a research methodology. Qualitative content analysis is one of the several qualitative methods currently available for analysing data and interpreting its meaning (Scheier, 2012). As a research method, it represents a systematic and objective means of describing and quantifying phenomena (Downe-Wamboldt, 1992; Schreier, 2012). A prerequisite for successful content analysis is that data can be reduced to concepts that describe the research phenomenon (Cavanagh, 1997; Elo and Kyngäs, 2008; Hsieh and Shannon, 2005) by creating categories, concepts, a model, conceptual system, or conceptual map (Elo and Kyngäs, 2008). The research question specifies what to analyse and what to create ((Elo and Kyngäs, 2008; Schreier, 2012). QCA is mainly inductive; that is, research questions guide data gathering and analysis. Its main objective, is 'to capture the meanings, emphasis, and themes of messages and to understand the organization and process of how they are presented'. Relatedly, Krippendorff (2004, p. 00) refers to the objective of QCA as follows: '[to] search for multiple interpretations by considering diverse voices (readers), alternative perspectives (from different ideological positions, oppositional readings (critiques), or varied uses of the texts examined (by different groups).

The data used in content analysis studies must satisfy, at least, two conditions; first, the data must provide useful evidence for testing hypotheses or answering research questions; and, second, the data communicate or provide a message from a sender to a receiver. Both conditions are quite satisfied in the data of the present study; namely, Fielding's work, Tom Jones. Moreover, in QCA studies, including the present study, the data are subject to purposive sampling to allow for identifying complete, accurate 
answers to research questions. It is, also, important to emphasize the point that selection of the data has been a continuous process. Analysing the data is integrated into coding much more in qualitative content analysis than in quantitative content analysis. The emphasis is always on answering the research questions.

The most widely used criteria for evaluating qualitative content analysis are those developed by Lincoln and Guba (1985). They used the term trustworthiness. The aim of trustworthiness in a qualitative inquiry is to support the argument that the inquiry's findings are 'worth paying attention to' (Lincoln and Guba, 1985). This is especially important when using inductive content analysis as categories are created from the raw data without a theorybased categorization matrix. Several other trustworthiness evaluation criteria have been proposed for qualitative studies (Emden et al., 2001; Lincoln and Guba, 1985; Neuendorf, 2002; Polit and Beck, 2012; Schreier, 2012). However, a common feature of these criteria is that they aspire to support the trustworthiness by reporting the process of content analysis accurately. Lincoln and Guba (1985) have proposed four alternatives for assessing the trustworthiness of qualitative research, that is, credibility, dependability, conformability, and transferability.

\section{Literature review}

\section{Discourse: Three approaches to discourse analysis}

Defining 'Discourse'. 'Discourse', used as a mass noun, means roughly the same as 'language use' or 'language-in-use'. As a count noun (a discourse), it means a relatively discrete subset of a whole language, used for specific social or institutional purposes. More specifically, 'discourse' as a mass noun and its strict linguistic sense, refers to connected speech or writing occurring at suprasentential levels. As Van Dijk (1985) points out, our modern linguistic conception of discourse (as language use) owes much to the ancient distinction between grammar and rhetoric. Grammarians explored the possibilities a language can offer a 'calculus' for representing the world, and were concerned with correctness of usage. By contrast, rhetoricians focused upon practical uses of speech and writing as means of social and political persuasion. In this regard, Georgakopoulou and Goutsos (1999) point out "despite the centuries-old tradition of the mother discipline of rhetoric, three decades ago there were only two isolated attempts to study language beyond the sentence with specifically linguistic methods; namely Harris (1952) and Mitchell (1957).

The approaches to discourse analysis. There are three main approaches to discourse and its analysis in contemporary scholarship: (1) the formal linguistic approach (discourse as text); (2) the empirical sociological approach (discourse as conversation) and (3) the critical approach (discourse as power/knowledge). It should be borne in mind, however, that each approach is, in itself, a multi-disciplinary; each has its own controversies, and contradictions. However, each is sufficiently different from the others.

The Text-Linguistic Perspective is often referred to as the 'formal approach' to discourse. It tends, largely, to construe discourse as text. It is the most direct descendant of Harris (1952) and Mitchell (1957). Like Harris, it continues to have faith in formal linguistic methods of analysis. Like Mitchell, it moves linguistics, as a different discipline, as mainly been in the direction of social functions and naturally occurring samples. A more recent heir to the formalist approach has been 'Text Linguistics' (TL). The term was pioneered by Van Dijk (1972) and later developed by De Beaugrande $(1980,1984)$ though Van Dijk has, to some extent, recast TL as discourse analysis.

As previously mentioned, the ongoing use of texts in their communicative environment; that is, in their contexts, has been referred to as 'discourse'. 'Discourse' and 'text' have been used in the literature in a variety of ways. In some cases, the two terms have been treated as synonyms, while in others the distinction between discourse and text has been taken to apply to units of spoken versus written communication. Consequently, discourse analysis is, in some accounts, regarded as concerned with spoken texts (primarily conversation). Text linguistics, as a different discipline, has mainly been associated with written texts. According to Georgakopoulou and Goutsos $(1999$, p. 3$)$ the two terms do not refer to different domains (speech and writing) but reflect a difference in focus. In this regard, Slembrouk $(2003$, p. 1) points out that "Discourse analysis does not presuppose a bias towards the study of either spoken or written language. In fact, the monolithic character of the categories of speech and writing is increasingly being challenged". Discourse, then, is the umbrella term for either spoken or written communication beyond the sentence. Text is the basic means of this communication, be it spoken or written, a monologue or an interaction. Discourse is, thus, a more embracing term that calls attention to the situated uses of text: it comprises both text and context. However, text is not just a product of discourse, as customarily assumed (Brown and Yule, 1983), that is, the actual (written or spoken) record of the language produced in an interaction. Text is the means of discourse, without which discourse would not be a linguistic activity (see El-dali, 2011, 2012, 2019a, 2019b; Boisvert and Thiede, 2020; Hart, 2020).

The empirical approach consists of sociological forms of analysis which have taken 'discourse' to mean human conversation. Its object has been not merely the formal description of conversational 'texts', but also the common sense knowledge at the basis of conversational rules and procedures. The most fruitful work to date has been accomplished in the area of conversation analysis (CA). The major strength of conversation analysis lies in the idea that an important area of interactional meaning is revealed in the sequence. Its most powerful idea is that human interactants continually display to each other, in the course of interaction, their own understanding of what they are doing. This, among other things, creates room for a much more dynamic, interactional view on speech acts.

In Fairclough's words, (1992, p. 7) the critical approach "is not a branch of language study, but an orientation towards language ... with implications for various branches. It highlights how language conventions and practices are invested with power relations and ideological processes which people are often unaware of". To that end, this approach investigates language behavior in everyday situations of immediate and actual social relevance: discourse in education, media and other institutions. It does not view context variables to be correlated to an autonomous system of language; rather, language and the social are seen as connected to each other through a dialectical relationship. Texts are deconstructed and their underlying meanings made explicit; the object of investigation is discursive strategies which legitimize or 'naturalize' social processes (Orpin, 2005; K. O’Halloran, 2007; Campbell and Roberts, 2007). Van Dijk (2006, 2008a, 2008b) argues that it is not the social situation itself that influences the structure of text and talk, but rather the definition of the relevant properties of the communicative situation by the discourse participants. Van Dijk (2008a, p. ix) argues that "the new theoretical notion developed to account for these subjective mental constructs is that of context models, which play a crucial role in interaction and in the production and comprehension of discourse. They dynamically control how language use and discourse are adapted to their situational environment, and hence define under what conditions they are appropriate". According to Van Dijk, context models are the missing link between discourse, communicative situations and society, and hence are also part of the foundations of pragmatics. As Van Dijk (2008a, p. vii) points out "in most of the disciplines of the humanities and social 
sciences there is growing but as yet unfocused interest in the study of context".

In conclusion, "while it is correct to say that discourse analysis is a subfield of linguistics, it is also appropriate to say that discourse analysis goes beyond linguistics as it has been understood in the past ... discourse analysts research various aspects of language not as an end in itself, but as a means to explore ways in which language forms are shaped by and shape the contexts of their use." At the same time, discourse analysis is a cross-discipline and, as such, finds itself in interaction with approaches from a wide range of other disciplines. Discourse analysis is, thus, an interdisciplinary study of discourse within linguistics: "Discourse analysis is a hybrid field of enquiry. Its 'lender disciplines' are to be found within various corners of the human and social sciences, with complex historical affiliations and a lot of cross-fertilization taking place" (Slembrouk, 2003, p. 1). It must be emphasized, however, that a single, integrated and monolithic approach is actually less satisfactory than a piecemeal and multi-theoretical approach.

Language, linguistics, and literature. Language is one of the most important aspects of communication. Nowadays, we can find almost everybody around us using a particular language to communicate. Language is a wonder as it helps to spread our ideas, thoughts and let others know about our mood through time, space and culture. In addition, if one were to take an informal survey among non-linguists regarding the primary function of human language, the overwhelmingly most common answer would be, "language is used for communication". As Van Valin (2001, p. 319) maintains, "this is the common sense view of what language is for". However, some of the most prominent linguists in the field reject this view, and many others hold that the fact that language may be used for communication is largely, if not completely, irrelevant to its study and analysis (See Evans, 2018: Simpson et al., 2018; Mooney et al., 2011). In other words, the majority of professional linguists used to adopt a view of language which is at odds with the view held by non-linguists. The phenomenon of communication has often been thought of as peripheral in linguistic research. This view is a result of the strong hold the abstract objectivist language conception has had on modern linguistic thought. Communication has been reduced to a subordinate place amongst the possible functions of language. This low status attributed to communication is challenged by different pragmatic approaches to language. On the other hand, the content and use of the term 'communication' is even by humanistic standards extremely ambiguous, and it has, therefore, often been difficult to use in practical, empirical work.

The primary concern of linguists such as Franz Boas and Ferdinand de Saussure at the start of the $20^{\text {th }}$ century was to lay out the foundations for linguistic science and to define explicitly the object to be investigated in linguistic inquiry. Carston (1988, p. 206) points out that "before Chomsky, linguistics tended to be a taxonomic enterprise, involving collecting a body of data (utterances) from the external world and classifying it without reference to its source, the human mind." Chomsky (1965) proposed a distinction analogous but not identical to Saussure's and Bloomfield's, namely competence vs. performance. In his distinction, Chomsky sees that the proper domain of linguistic inquiry is competence only. In the Chomskyan linguistic tradition, well-formedness plays the role of the decision-maker in questions of linguistic 'belonging'. That is, a language consists of a set of well-formed sentences: it is these that 'belong' in the language, no others do. This is the definition that has been the bulwark of the Chomskyan system since the late 1950s.

Linguistic studies which depend upon elicitations from only one or a few informants are now recognized as leaving unanswered many significant questions about the relation between language and the social context in which it is always embedded. Language is no longer viewed "as a closed system, but as one which is in perpetual flux" (Johnson, 2002, p. 16). Moreover, the extraordinary growth of sociolinguistics in the last decade or so has shown convincingly that language is closely linked to its context and that isolating it artificially for study ignores its complex and intricate relation to society.

The idea of extending linguistic analysis to include communicative functions was, first, proposed by Czech linguists. As Van Valin (2001, p. 328) points out, "all contemporary functional approaches trace their roots back to the work of the Czech linguist Mathesius. By the end of the 1970s, a number of functional approaches were emerging in both U.S. and Western Europe. Some of the most important and coherent attempts of communication-relevant approaches to language are (1) Soviet Semiotic Dialogism; (2) The Prague School, and (3) Functionalism (see McHoul, 1994). More specifically, Halliday attempted to explain the structure of language as a consequence of social dialogue. According to Halliday (1978, p. 2), language does not consist of sentences; it consists of interactional discourse. People exchange meanings in socially and culturally defined situations. When they speak to each other, they exchange meanings, which reflect their feelings, attitudes, expectations and judgments. In this regard, Bates (1987) noted that functionalism is like 'Protestantism', a group of warring sects, which agree only on the rejection of the authority of the Pope. All functionalists agree that language is a system of forms for conveying meaning in communication and, therefore, in order to understand it, it is necessary to investigate the interaction of structure, meaning and communication. As Van Valin (2001) points out, functionalists normally focus on linguistic functions from either of two perspectives; the first is referred to as the 'pragmatics' perspective, and the second as the 'discourse' perspective. The first concentrates on the appropriate use of different speech acts. The second perspective is concerned with the construction of discourse and how grammatical and other devices are employed to serve this end.

Employing the linguistic rules on artistic works results in what is known as stylistics. It has to do with the different uses of words, expressions, sentence-structures and speech sounds in a given text. Stylistics is a branch of linguistics, while the latter investigates no units larger than a sentence, the former examines bigger units of linguistic formation. Such bigger units of linguistic formation, constitute the context of a work, known as the style of an author. The way of writing of an author is also called register. Chapman (1973, p. 11) states that the distinctive usages of languages are known as styles; and that the "Linguistic study of different styles is called stylistics". Stylistic analysis of a given text which functions through linguistics, primarily aims at the analysis of discourse in such text. Short (1986, p. 158) states that the stylistic analysis has to do with criticism, through which evaluation, interpretation, and textual description of a literary work are identified. The realtion of linguistics to literary criticism is what Chomsky $(1968$, p. 81 ) has called, "The close relation between innate properties of the mind and features of linguistic structure".

The importance of conducting a study of literary language by means of linguistics, has taken the form of 'Discourse Analysis'. However, the application of linguistic characteristics to literary texts, has proved that literature has linguistic form and that some sort of harmony exists between linguistics and literature. Stylistics which is a branch of linguistics, investigates the relationship between style and literary function or the application of linguistic characteristics to literary language. Richards (1985) states that stylistics is associated with the study of style, based on the 
situation in which the writer, speaker or addressor intends to create on the reader, hearer or addressee. Although stylistics sometimes contemplates spoken language, it mainly refers to the study of written language. The different uses of words, expressions, sentence-structures and speech sounds are incorporated with the stylistic characteristics of a given text. Carter (1986, p. 19) says that there are two branches of stylistics, namely linguistic stylistics and literary stylistics. The former kind studies ways of anlysing samples of style and language, especially the non-liteary language. The latter kind of stylistics, namely, literary stylistics, studies methods of conceiving, interpretating and estimating the literary works, by virtue of criticism. It also studies ways of analysing literary discourse, especially as regards the narrative techniques. Leech $(1981$, p. 11) states that stylistics, "is simply defined as the linguistic study of style ... (and) simply (is) an exercise in describing what use is made of language". In the meantime Leech tries to explain the aim of literary stylistics, indicating that its target is to expound the relationship between language and the artistic function.

The function of stylistics is to expound interpretations already existing within the context of a comprehensive unit of linguistic performance. Short (1986) attempts to enumerate levels of interpretation within a literary discourse. "Copiousness", for instance examines sentences in case that "they are long and have lots of clauses within them". "Simplicity" examines the style, if it is simple or not. Simple style shows that an author does not attempt to puzzle the reader by complex formations. "Sequencing" among the levels of interpretations reflects the order in which the events of a discourse has taken place, the order in which the thoughts of a character in a literary work have occurred and the order in which the addressor or the writer depicts the information to his addressees or readers.

Style indicates the route in which language operates in a given context. Style is a term used to show the function of language in spoken and written discourse as well as in literary and nonliterary fields. The word in its wide sense, covers also the way of writing of any author; and it is an instrument by virtue of which, a linguist could examine the choices worked out by an author in a particular context. Style also identifies the method of using language either during a certain era or by a certain school of writing. In this connection Leech (1981) states that style is "the linguistic characteristic of a particular text". He adds that style is "a property of all texts". Fowler (1971) states that style is examined on two levels; the first is the level of context which includes all utterances within a text and utterances in their term are formed through a successinve sequence of sentences. Brown (1983) differentiates between sentences and utterances, stating that the features of spoken language are considered the features of utterances and that the characteristics of written language belong to sentences. However, the features of utterances are the output of ordinary language beahviour. The second level of style is examined within the framework of the form including ways of organisation within a text. Style includes two models. Lang (1983) says that the first model of style is associated with the noun, dealing with the stylistic practice, only to attach to an object the names of genres, figures of speech or periods of time. The second model of style is that which has a nominative function dealing with categories of style, including life styles, styles in dress or artistic style. Chapman (1973, p. 6) quotes Quiller Couch's remark on style saying that, "Style in writing is much the same as food manners in other human intercourse".

The modern work in linguistic stylistics have divided style into various types. Freeman (1970) says that there are three types of style; style deviating from a specified course; style as divergence of textual pattern and style utilizing grammar potentials. The former kind of style is that which suggests that an author's method of writing could differ in certain ways in various fields of utilization. The second kind of style is associated with examination of the coherence elements within a text. Cohesion for instance examines the use of determiners, pronouns, demonstratives, and adverbs as being hinted before. Lack of cohesion affects the literary prose. The last kind of style accounts for a kind of grammar that foretells the language used in a text. In this connection, language is to be judged on two levels of representaiton, the deep and surface syntactic structures. Semantic interpretation proceeds from deep structure and phonetic interpretation proceeds from deep structure and phonetic interpretation stems from surface structure. The two levels are related by a set of transformations and the use of particular sets of transformations shape the syntactic style of an author. Any kind of style to be undertaken by an author is to be called "register". Using a particular kind of style such as the religious style or the legal style, probably means that an author is adopting a 'register'. Fowler (1971) quotes Leech attempting to identify register saying "(it distinguishes) for example, sopken language from written language, the language of respect from the language of condescension, the language of advertising from the language of science". Register is a speech variety used by a particular group of people usually sharing the same occupation. Richards (1985) says that register is, "a particular style ... referred to as a stylistic variety".

Chapman (1973) states that it is highly important that a writer chooses registers aligning the situations they depict. Combining a number of registers together without idnetifying the speakers and the shifting of utterances are subjects worthy of study through stylistics. According to Leech (1981) style in discourse is divide dinto three categories of language use, namely, domain, mode and tenor. Domain is the scale of register. The professional jargon in a certain variety of language is the typical feature of domain. The language of science differes from that of engineering. Thus domain seems to deal with the activity of language within a specific context. The distinction between speech and writing is oncorportated within the category of mode. The relaitonship between the speaker and the addressee(s) is the focal point in the category of tenor. Their relationship whether official and distant, or unofficial and close determines the way of use, either formal and complex or informal and simple; polite showing indirect request or familiar showing direct imperative, impersonal done in the passive form of personal done in the active form. However, the category of tenor in the literary works has to do with the point of view operational in such activities. As long as such viewpoint is to be communicated through language, then the medium of language has to be also investigated (see Peck, 2011; Hardavella et al., 2017; Fong Ha et al., 2010).

Stylistics and literary studies. Referring to the title of her article 'Fielding's Style', Campbell (2005, p. 407) made the following remark: "The topic announced by this essay's title is seemingly old-fashioned-perhaps some would even say, reactionary. The word "style" invokes questions of aesthetic appreciation that several decades of contextualizing criticism in the 1970s, and 1990s moved far from the center of literary study; to attempt to describe an individual author's style might seem to bespeak an antiquated belief in some ineffable quality adhering in that author, independent of his historical period or circumstances and of the import of his work". In what follows, I will show how important it is to link linguistics to literature and to what extent stylistics is valuable. As Levine (1996) points out "[W]e have to understand that if there is no literature, there is no profession [of literary studies]". Less strictly pragmatically, he added his spare attestation of faith that literary study consists of "reading the sorts of texts that test most fully the possibilities of language and 
meaning, and using skills developed to engage those texts successfully. In this regards, McIntyle (2012, p. 1) points out that since the emergence in the 1960s of English Language as a university subject in its own right, the relationship between the study of literature and the study of language has often been one of bitter rivalry. Literary critics have railed against the 'cold', 'scientific' approach used by scholars of language in their analyses of literary texts, whilst linguists have accused their literary colleagues of being too vague and subjective in the analyses they produced. Nowhere is this disagreement more clearly seen than in the clash between Bateson and Fowleer (see Fowler, 1971), which had the unfortunate effect of dragging the debate down to the level of personal insult. Fowler's famous question to Bateson asking him whether he would allow his sister to marry a linguist represents, perhaps, the nadir of this particular argument. The relationship between literature and language, then, has, for the most part, been an unhappy one, and this is unfortunate since undoubtedly scholars in both disciplines have much to learn from one another. It is possible to bridge the divide between language and literature by using the anlytical techniques available within the subdiscipline of language study known as stylistics. Taking a linguistic approach to the analysis of a literary text does not have to mean disregarding interpretation. Stylistic analysis can often illuminate just why a particular literary text is regarded so highly. Stylistics acknowledges the skills of the writer by assuming that every decision made in the production of a text is deliberate, despite whether these decisions were made consciouly or unconsciously. Consequently, stylistics aims to explain the link between linguistic form and literary effect, and to account for what it is that we are responding to when we praise the quality of a particular piece of writing.

A further aspect of textual analysis with which some stylisticians concern themselves and about which others have reservations, is the study of the extent to which interpretation is influenced by tensions between the text and its reception in the wider context of social relations and socio-political structures. In some contexs stylistic analysis has become embedded within a framework of Critical Discourse Analysis (CDA). In this way, explorations of ideology and social power feature as part of a stylistic analysis with attention paid both to the formal features of the text and to its reception within a reading community. This development has been the subject of some controversy, not least because all texts chosen for analysis may generate ideological considerations and interpretations according to the disposition of the individual analyst. Nevertheless, despite such criticisms, CDA has been the first attempt so far to formalise a methodology that seeks to articulate the relationship between a text and the context in which it is produced, received and interpreted, thus moving beyond a concern with wholly text immanent interpretation and considering wider social and cultural issues. Thus, what has emerged in both theory and classroom practice is the view that, although there are not an infinite number of possible interpretations and although it would be wrong to suggest that anything goes, there is no single 'correct' way of analysing and interpreting the text. In this sense, the appropriate method is very much a hands-on approach taking each text on its own merits, using what the reader knows, what the reader is aiming for in his or her learning context, and employing all of the available tools, both in terms of language knowledge and methodological approaches. It is a process-based methodology which encourages learners to be active participants in and explorers of linguistic and cultural processes both with an awareness of and an interest in the process itself, including the development of a metalanguage for articulating responses to it.

On the other hand, the last twenty years have seen significant advances in linguistics, education and literary and cultural theory, a development that has provided a strong basis for exploring texts using a diverse range of methodologies (see Hall, 2005 for a comprehensive survey). Literary theory has embraced many topics, including the nature of an author's intentions, the character and measurement of the responses of a reader and the specific textuality of a literary text. In particular, there has also been a continuing theorisation of the selection of literary texts for study, which has had considerable resonance for the teaching of literature and for its interfaces with the language classroom. On the one hand, there is a view, widespread still internationally, that the study of literarure is the study of a select number of great writers judged according to the enduringly serious nature of their examination of the human condition. On the other hand, there is the view that the notion of literature is relative and that ascriptions of value to texts are a transient process dependent on the given values of a given time. How tastes change and evaluations shift as part of a process of canon formation are therefore inextricably bound up with definitions of what literature is and what it is for. In this respect, deftnitions of literature, and of literacy language are either ontological establishing an essential, timeless property of what literature or literary language is - or functional - establishing the specific and variable circumstances within which texts are designated as literary, and the ends to which these texts are and can be used. Recent work on creativity and language play has reinforced this awareness of both continuities and discontinuities in degrees of literariness across discourse types (Cook, 1994, 2000; Pope, 2005). One outcome has been the introduction into language curricula, for both first and for second or foreign language learners, of a much greater variety of texts and text-types so that literary texts are studied alongside advertisements, newspaper reports, magazines, popular song lyrics, blogs, internet discourse and the many multi-modal texts to which we have become accustomed (see Carter, 2010).

In the early part of the twentieth century, learning a foreign language meant a close study of the canonical literature in that language. In the period from the 1940s to the 1960s literature was seen as extraneous to everyday communicative needs and as something of an elitist pursuit. However, in the 1970 and 1980s the growth of communicative language teaching methods led to a reconsideration of the place of literature in the language classroom with recognition of the primary authenticity of literary texts and of the fact that more imaginative and representational uses of language could be embedded alongside more referentially utilitarian output. This movement has been called the 'proficiency movement' which saw in literature 'an opportunity to develop vocabulary acquisition, the development of reading strategies, and the training of ctitical thinking, that is reasoning skills'. They point out how awareness dawned that literature, since it had cominuittes with other discourses, could be addressed by the same pedagogic procedures as those adopted for the treatment of all texts to develop relevant skills sets, especially reading skills, leading in particular to explorations of what it might mean to read a text closely (see Alderson, 2000).

Controversial views of Henry Fielding. In his survey of Henry Fielding, Hume (2010) attempted to remind readers of two major issues: (1) just how wildly views of Fielding have varied, early and late; and (2) how radically the dominanat late twentieith-centrury reading contradicts eighteenth-century assessments of Fielding and his work. Henry Fielding, according to Hume, proved exceptioally controversial and his reputation has variously soared and crashed in the course of three centuries. Fielding's reputation suffered from two factors. The first is that he wrote about low subjects. He did not always preserve the dignity of the clergy; his work features bastards and fornicators; the world of crime and 
squalor depicted even in the relatively exemplary Amelia bothered many of his genteel readers. For his time, he was much more radical writer than most readers now realize. The second factor that guaranteed the blackening of Fielding's reputation was the history of his changing political allegiances and his scandalous personal life. His appointment as justice of the peace for Westminister in October 1748 and his becoming magistrate for Middlesex County provoked ridicule and hostile outcry.

Fielding's disorderly personal life put ammunition into the hands of his litrary enemies, who seized on the lowness of his fictional subjects with spiteful glee. The picture one gets from public and private commentary during Fielding's lifetime is of a hard-living man of violent passions (positive and negative) who could not manage money competently and could or would not accommodate himself to the codes and pretenses of an urbane upper class to which he did not really belong. Fielding's reputation, as Rawson (1959) observes "always suffered from that eighteenth-century cult of 'sensibility' which professed itself too refined for scenes of coarse or low life, and too tender-hearted for satire". Fielding was not without some defenders. Harold Child points out that "Fielding established the form of the novel in England"; that Tom Jones (1749) entitles him to be called "the father of the English novel"; and that he "had fixed the form of a new branch of literature".

Early nineteenth-century writers are less fixated on the writer's life. During the twentieth-century, critical evaluation of his writing underwent a drastic change. For fully two hundred years, Fielding was usually seen as "the great structuralist and technician" and contrasted with Richardson-"the great moralist". Fielding was sometimes condemned for being crude and immoral, sometimes praised for realism, and sometomes just enjoyed as a creator of jolly English romps. His literary morals were sometimed defended, but hardly anyone saw him as a writer whose cenrtral concern was moral instruction. The radical reorientation that occurred in the ways Fielding was read and understood is now largely associated with Battestin's The Moral Basis of Fielding's Art (1959). For a majority of the critics of the last half century, moral sermonizing is what has been taken as "most characteristic" of Fielding. In addition, Hume (2010, p. 258) argues that Fielding's writing has three major characteristics. The first is that Fielding is experimental; in the sense that he is not trying to associate himself closely with predecessors and traditions. Fielding's debts to earlier writers are unusually minimal, and he does not stick to one or two models in drama or fiction. He innovates, experiments, and takes chances. A second major feature of Fielding's writing is that it is circumstantial. Fielding deals with and reacts to the events, issues, politics, quarrels, social problems, and stresses of his place and time, and he does so as a hackney writer out to make a quid. He does not imagine alternative worlds, idealized worlds, or past worlds. He is an engaged observer, a participant, a partisan. He is an opportunist who will keep silent or change sides; he puts the advantage of occasion above abstract principle, moralist through he is. Fielding deals-sometimes humorously, sometimes notwith a grubby milieu of crime, deceit, and lust. What many of his contemporaries condemned as "low" we should regard as "realistic", at least in the terms of literature as it was written in Fielding's time.

A third characteristic of Fielding's writing is its didacticism:

I say this with some hesitation, because didacticism is not a positive quality for most present-day readers, academic or otherwise, who regard it as boring, irritating, and preachy (Hume, 2010, p. 259).

Today Fielding is universally acknowledged as a mjor figure in the development of the novel, although there is still niggling about whether he or Richardson is the "father" of the British novel.

\section{Discussion}

Fielding's narrative technique. Choosing a narrative point of view is perhaps the most important and most difficult decision a writer of a story can make. Point of view, like plot, character, setting, and language is a creative decision; however, it is also very much a technical decision. Someone has to tell the story. That someone is called the narrator. The question is who will that narrator be and what does that narrator know. Abrams (1981, p. 142 ) identifies the point of view, saying that it "Signifies the way a story gets told, the mode or perspective established by an author by means of which the reader is presented with the characters, actions, setting and events which constitute the narrative in a work of fiction".

The point of view in a literary composition represents the aspect from which the story telling and seeing is calibrated. It does not only represent the dimension from which the author projects his scene but also sets out the aspect from which the reader is to view it. Point of view is the perspective from which a story is narrated. Every story has a perspective, though there can be more than one type of point of view in a work of literature. The choice of the point of view from which to narrate a story greatly affects both the reader's experience of the story and the type of information the author is able to impart. First person creates a greater intimacy between the reader and the story, while third person allows the author to add much more complexity to the plot and development of different characters that one character wouldn't be able to perceive on his or her own. The point of view in an artistic work represents the significance of its overall form. Tackling the significance of the point of view, Allot (1959, p. 181) indicates that the most complicated matter in the craft of fiction is "... to be governed by the question of the point of view-the question of the relation in which the narrator stands to the story". Point of view is very closely linked with the concept of a narrator. Point-of-view impacts how close the reader feels to what's happening in the story. The narrator acts, as a proxy for the reader and how close the narrator is to the story is how close the reader will be to the story (see Peck, 2011; Hardvell et al., 2017).

The narrators of Fielding's Tom Jones focus on the omniscient point of view in which the third-person narrative is outside the story referring to characters either by their name or by the pronouns, "he, she and they". An omniscient narrator is more able to present a complete and unbiased story. We can learn not only what a character does, but also what other characters do when the main character is not present. Abrams (1981, p. 143) sees that the narrator of the omniscient point of view "knows everything that needs to be known about the agents and events; that he is free to move as he will in time and place, and to shift from character to character, reporting ... what he chooses of the speech and actions; and also that he has privileged access to a character's thoughts and feelings and motives, as well as to his overt speech and actions". The narrator begins Joseph Andrews: "Mr. Joseph Andrews, the hero of our ensuing history, was esteemed to be the only son of Gaffer and Gammer Andrews ... whose virtue is at present so famous" (Book 1, Ch. 2, p. 41). It is also the way that the narrator of Tom Jones starts "In that part of the Western division of this kingdom which is commonly called Somerset-Shire, there lately lived, and perhaps still lives a gentleman, whose name was Allworthy ..." (Book 1, Ch. 2, p. 53).

The narrator tends to put the overall work into a wellbeing form; he plays the God-like role and the ruler who presides over his fictitious or real formation. The narrator spells out the 
function he undertakes "The writer may be celled in aid to spread their history farther, and to present the amiable pictures to those who have not the happiness of knowing the originals; and so by communicating such valuable patterns to the world, he may perhaps do a more extensive service to mankind ..." (Book 1, Ch. 1, p. 39). The writer in this respect seems to have almost cognizance of the historical aspects and thus he presents just those patterns which are of vital importance to the service of mankind. Allot (1959, p. 188) states that the eighteenth century writers among them Fielding, attempt to adopt the first person narrative view-point within the context of an exterior third person narrative. This is of course, clearly hinted in the digressive tales of the two books which are merely old methods of narration.

Throughout The History of Tom Jones, A Foundling (1749) Henry Fielding makes his presence felt. He lectures, teases and cajoles the reader, ponders the difficulties of his task, and draws attention to his deft arrangement of material. In short, he never lets us forget that he is telling a story, and that we are reading a book. One of the most prominent features of Fielding's intrusive narration is his frequent direct address to an imagined reader. The characteristic Fielding most frequently attributes to his reader is sagacity. Early in the novel, for example, after comparing Mrs. Wilkins-Squire Allworthy's formidable housekeeper-to a bird of prey, he breaks off:

The sagacious Reader will not, from this Simile, imagine these poor people had any Apprehension of the Design with which Mrs. Wilkins was now comong towards them; but as the great beauty of the Simile may possibly sleep these hundred years, till some future commentator shall take this Work in hand, I think proper to lend the reader a little Assistance in the Place.

Fielding constantly makes reference to the reader's sagacity, or speculates as to how his 'Sagacious Reader' might interpret a particular scene. In all, he uses the word sagacious and its cognates ('sagacity', 'sagaciousness', etc.) 41 time when speaking in his own person. It is never used by any other character. Fielding narrative style was much imitated in the decade following the publication of Tom Jones. Early in the novel, having introduced us to the principla characters, Fielding announces that he wil pass over a space of around twelve years in silence (since the incidents which took place in this period are not immediately relevant to his narrative), and in doing so reflects on the nature of his relationship with the reader:

We give him all such Seasons an Opportunity of employing that wonderful sagacity, of which he is Master, by filling up these vacant Spaces of Time with his own Conjectures; for which Purpose, we have taken care to qualify him in the preceding Pages (T.J. III.i, p. 116).

From the very beginning of the book, the reader is acquainted with the fact that the story will be formed in proportion to the self-conscious caprice of an individual, pertaining to the outward existence of the world of the book. The work is categorized as an art as much as a reflection of life. The book begins with the introduction of the author as regards the narrative role. The course of events is worked out by a skilful artist and the progress of the novel's picaresque episodes are not known in advance. Fielding's technique in his novels is dissimilar to that adopted in Richardson's novels, mostly undermines the existence of genuine suspense, "what will happen next?" Although heroic persons and sublime thoughts are major components of characters and sentiments in the epic genre, they are undermined in Tom Jones. As for the epic diction, it is highly used in burlesque form. Fielding's marked imitation of the epic action is the mock heroic battles with obvious realism and with the life of the time. A distinction has been drawn between burlesque and comedy, while the former makes a subject appears ridiculous by treating it in an incongruous style as by presenting a lofty subject with vulgarity, the latter makes a subject appear humorous in its treatment of theme and character. Incongruity and absurdity are the sources from which we derive our delight at burlesque. They are also the essence of our delight at affectation, being the representation of the ridiculous. On attempting a distinction between burlesque, or its synonym ridicule, and comedy, Fielding is rectifying what has been said by Locke about the 'abuse of words', which is manifested in a gap between word and things (see Simpson et al., 2018; Mooney et al., 2011; Hammudin, 2012): “An author ought to consider himself, not as a gentleman who gives a private or eleemosynary treat, but rather as one who keeps a public ordinary, at which all persons are welcome for their money" (Fielding's Tom Jones, Bk 1, Ch. 1, p. 51). Meeting the narrator early in the book before the hero, is significant; since the narrator is neither objective nor omniscient, but rather a deliberate awareness whose relationship with the reader influences his interpretation and judgment of what is going on.

James (1968, pp. 13-14) has felt sorry that Tom, the hero, has fallen a prey to clouds of mind, perplexity and confusion, although a hero in his own eyes ought not to be in such a situation. He suggests that the author of Tom Jones: "handsomely possessed of a mind, has such an amplitude of reflexion for him and round him that we see him through the mellow air of Fielding's fine old moralism, fine old humour and fine old style, which somehow really enlarge, make everyone and everything important". Werner (1973, p. 71) points out that Fielding's narrative technique is indeed complex. Miller indicates that his rhetoric is carefully calculated to achieve specific ends. All these are indicators that Fielding, unlike Richardson, does not explore the depths of human nature but registers the external surface of the human behaviour (Miller, 1981, p. 209). Fielding's most successful works stand closely with Swift rather than Richardson. Fielding resembles swift as both stress the importance of the uses of language. Accordingly, the narrative consciousness becomes important; it does not only project awareness but also affects the response of the reader and his reappraisal of the presented material.

Henry Fielding and the technique of irony in Tom Jones. Hume (2010, p. 285) points out that our concept of early eighteenthcentury satire is heavily colored by the array of books and articles published in the third quarter of the twentieth century by such eminent scholars as Maynard Mack, Ian Jack, Robert C. Elliott, Alvin Kernan, and Paulson. Their notions came largely from Pope and Swift, for whom attack was the basic motivation of satire. This is rarely true for Fielding, for whom instruciton is much more central.

Arriving at the truth is a focal point on the level of the plot of Tom Jones. The story begins with an esoteric and obscure birth and ends with the unraveling of this mystery. When the truth is revealed the book has given a line of unity. The theme of the novel is marked by ways of unfolding truth and divulging deceit. Irony which is used throughout the book enhances this theme, since it is built on double meaning, and on this account one attempts to seek the truth, which, lies behind the false appearance. Hatfield claims that Fielding: "Takes a word which, by virtue of the abusage of 'custom' has already a kind of built-in ironic potential, and playing this ironigenic corrupt sense against the 'proper and original' meaning of the word that is developed in the definition of action, seeks to restore the word to its rightful dignity of meaning" (Hatfield, 1968, pp. 191-192). Irony relies on double connotations of meaning that, are to be supplied by the 
narrator, but this does not suggest that it is based on custom. A further point, Fielding does not intend by writing a novel to restore a word to its rightful dignity of meaning, unless it is meant by Hatfield that he attempts to eliminate any corrupt use of a word. Hutchens $(1965$, p. 111) proposes that irony is produced by a gap between the accepted meaning of a word and its meaning in the context it occurs. However, Hutchens seems to be like Levine, as both consider irony not only a means through which, the nature of the characters is exposed but also it serves as a means of establishing truth. Hutchens states that: "The ... techniques, of connotative irony ... by suggesting what is not true or good or appropriate, throw into sharp relief what is" (Hutchens, 1965, p. 146).

Irony as one of the distinguished devices exploited in Tom Jones, mainly unravels connotations of meanings and the nature of the characters. Irony in the limited sense of the word is relevant to the use of words for conveying the opposite of their literal meaning; or it might be identified as an expression or utterance marked by a deliberate contrast between apparent and intended meaning. The aim behind these contrasts of meaning is to initiate humours or rhetorical effects. It might be notable as well that incongruity arises between what might be expected and what actually occurs. Fielding's target for fully exploiting the device of irony in Tom Jones is to delineate characters' behavior and conduct. Fielding's technique sheds light on the significance of irony end underlines the fact that language is not merely an inflexible conveyer of information but rather the reader's mind has to be more flexible end capable of grasping shades of meaning. Fielding's technique of irony also destabilizes the reader's assurance of his unscrutinized notions. It is the attitudes of the reader as much as those of the characters that are being subject to examination by the novelist (see Le Boeuf, 2007; Gibbs, 1994; Attardo, 2000; Chen, 1990; Barbe, 1995; Kruez and Roberts, 1993; Clark and Gerrig, 1984).

Irony is largely exploited and the distinction between 'love' and 'lust' is also voiced throughout the book. 'Justice' and 'mercy' as abstract values are also examined. The shifts in the narrative voice impels the reader to derive information either, from relying completely on the narrator or, from depending upon his own potentials for measuring the value of the narrator's claim, to know a particular fact or not. Empson (1982, p. 142) indicates that double irony is a means through which, the narrator, instead of adopting one level of meaning by exposing the flaws in another, 'may hold some wise balanced position between them, or contrariwise may be feeling a plague on both your houses. Empson seems to initiate a third indicator, namely 'qualified irony' in which, the narrator asserts that there is merit on both sides which, is one method of explaining the prudence of Mrs. Adams. Thus we can say that the basis of judgment of characters is gone under complex attempts. Levine (1996, p. 79) views irony in Tom Jones as a means of satirtic characterization. He concentrates on the way through which the characters are presented, but my concentration will be on the way through which, the nature of the characters is unfolded. Their nature shares some aspects of the reader's nature and thus the reader is invited implicitly to re-evaluate and perfectly judge the real aspects and qualities of the characters themselves as well as those of himself (see Kruez and Glucksberg, 1989; Brown, 1980; Mao, 1991; Glucksberg, 1995; Myers, 1977; Giora, 1995, 1997; Giora et al., 1997; Amante, 1981).

Irony is one of the four kinds of humour which might be operational in a fictional world. Satire, romance and farce are also regarded as types of humour. The difference among the four kinds could be reflected in the actions they represent. Lang (1983) says that farce emphasizes a kind of comedy characterized by loud, noisy and rough behavior. It leaves people at its end as they were at its beginning. The repetition which the farce suggests is the point which increases attraction to it. Romance often brings agreements in feelings, always in the form of marriage. Satire suggests ridicule and a form of mockery aiming to bring about a conflict. While farce depends upon the physical use of power and romance upon hopes and expectations, satire is designed to serve its end without elaboration.

Irony has a doubling effect, a surface level and a real depth, weakness and strength, affirmation and denial, all are included within an ironic view. The doubling effects of irony are forced on the investigator and it is his part to recognize the hidden ground. Irony is the major form of humour found in Fielding's discourse of his classics. Leech (1981) says, basing his view on Booth's (1974) ideas that irony represents some kind of 'secret communion' between the author and the reader. In case that such communion is undermined, then it is to be the author's inability to bring the reader in line with him, and not the reader's deficiency to comprehend the values presented by the author. Irony which represents contrasts in values within the framework of two different viewpoints could take place either in one sentence or in a comprehensive work. To depict the heroes and their companions with these changes in their characters, the author has employed ironic devices in his work to illuminate it. The importance of employing ironic techniques is to set up two opposite meanings for reinforcing the style and for urging the readers to understand properly the characters' behavior.

Fielding's Tom Jones, which is built on satire, tackles also two important concepts namely, charity and chastity, and it is through connotations of meaning that the author makes it difficult for the readers to make a simple judgment and thus complications arise for the evaluation of characters. Some puzzling questions are set up; do mercy, compassion and forgiveness contradict justice or not? But whether they contradict justice or whether they do not, are they regarded as virtues or vices? Do mercy, compassion, and forgiveness cause harm or reconcile? The problem is incorporated in the fact that the Christian religious doctrine asks for forgiveness, while the laws of justice ask for punishment; a culprit should get his deserts. The problem is also incorporated in the fact that it is difficult to know which cases deserve forgiveness and compassion and which do not. Those who wish to be charitable with either encourage vice and infringe the laws of justice or fulfil the laws of justice and condemn others. In both cases, no assertions of judging correctly are underscored as long as the evidence is not sufficient to communicate the truth. A judge has to avoid hasty judgment as long as judgment constitutes a major significance. He has to judge not only in accordance with the laws of justice but also in accordance with the laws of the religious doctrine.

Finally, Hume (2010, p. 260) made it clear that if we are trying to make sense of literature as it was written in the middle of the eighteenth century, we have to understand that most authorsFielding prominent among them-genuinely wanted to change the thinking and behaviour of their readers. They attempted to influence specific attitudes and actions relative to particular events, persons, and ideas, as well as more general loyalties. They sought to persuade-in personal, moral, and political terms. Battestin (1989) concurred in finding Fielding "fundamentally a moralist", but he insisted that "what is most memorable about Fielding is not his morality or his religion, but his comedy-the warm breath of laughter that animates his fiction". Fielding's writing is didactic but it is not preaching and there is a major difference. Fielding unquestionably has "designs" upon the reader: he almost always writes with conscious instructional purpose, not just for entertainment. He presents us with "realistic" lives and characters-realistic in his terms, not in ours-and he means us to sympathize, criticize, enjoy, and 
ultimately judge. Fielding has enormous bounce and humour and high spirits, but he is a profoundly didactic writer.

Fielding's characters in Tom Jones. The demonstration of characters is a two-edged weapon; it gives the narrator the freedom to expose specific moral or ethical considerations, in addition to expressing implications and restraining information, which affect the judgement of the reader. Actions and situations also contribute to defining the nature of certain concepts, such as charity and chastity. Fielding's characters are considered flat or, that is, static that they have no 'convincing inner life'. They do not change or enhance the course of events of the story. Fielding seems to be a close associate to Aristotle and Horace, as regards the flatness of characters. He proclaims that actions: "Should be likely for the very actors and characters themselves to have performed; for what may be only wonderful and surprising in one man, may become improbable, or indeed impossible, when related to another ... This requisite is what dramatic critics cell conservation of character, and it requires a very extraordinary degree of judgement" (Fielding's Tom Jones, BK viii, Ch. 1, p. 366).

Fielding is less inclined to describe the psychology of the characters but rather the qualities and peculiarities of them. Sometimes flat characters are described in a way which could not be mistakenly understood. For instance, it is stated that "Allworthy was, and will here after appear to be, absolutely innocent of any criminal intention whatever, 'which is one way describing an aspect of Allworthy's character to be fully perceived by the reader". In other cases, flat characters add complications to the reader's response, such as those described as 'notorious rogues' or 'abandoned jades', because in these cases, it is the reader's assumption of the qualities of the characters that is subject to change. Obviously, flat characters do not change or develop but rather it is the reader's perception of them that changes. Early in the book, the narrator makes fun of epithets given to persons, in accordance to one's needs. On blaming Jenny Jones for having a bastard son, she is described by Mrs. Deborah Wilkins as "a very sober girl" and by the housekeeper as an "audacious strumpet". Bridget on the other hand, states that she is one of those "good, honest, plain girl(s)" who are deceived by wicked men. Despite, Wilkins' previous condemnation of Jenny's attitude, she agrees with her mistress in her characterization. Referring to epithets to characterize the nature of persons, serves as a means of measurement and judgment. Sometimes the public judgment aligns that of the narrator, as is the case when Bilfil exposes the illicit catch incident of Tom and Black George?: "When this story became public, many people differed from Square and Thwackum in judging the conduct of the two lads on the occasion. Master Bilfil was generally called a sneaking rascal, a poor-spirited wretch; with other epithets of the like kind; whilst Tom was honoured with the appellations of a brave lad, a jolly dog and an honest fellow" (Fielding's Tom Jones, BK 111, Ch. 5, p. 134).

A different evaluation of the public is suggested later and it is Sophia's perception which maintains that "To say the truth, Sophia, when very young, discerned that Tom, though an idle, thoughtless, rattling rascal, was no-body's enemy but his own and that Master Bilfil, though a prudent, discreet, sober, young gentleman, was at the same time, strongly attached to the interest only of one single person; and who that single person was, the reader will be able to divine without any assistance of ours" (Fielding's Tom Jones, BK iv, Ch. 5, p. 162). Epithets in the abovementioned quotation are made obvious through inherent irony. Epithets also mirror the evaluation of the community. Tom at the age of twenty is called a "pretty fellow among the woman in the neighborhood; Allworthy when he dismisses Tom from his household is an "inhuman father"; Square is "what is called a jolly fellow or a widow's man". These epithets give the reader information which aids him in attempting judgment. Refraining from giving complete information about the characters evokes not only misconception among the characters themselves, but also misunderstanding about the characters in the reader's eyes. This is the case of Jenny Jones or Mrs. Waters. Her character is a little bit conserved as long as, it is not completely unfolded as Allworthy's or Tom's. Actions undertaken by the character's work consistently with their natures. Black George, for example, attempts to take possession of the five-hundred-pound note extended from Allworthy to Tom when banished from Allworthy's house. When Black George has met Tom after being dismissed, he is anxious lest Tom asks to borrow some money although "he had ... amassed a pretty good sum, in Mr. Western's service". In a further, situation, he gives Tom a sum of money amounting to sixteen guineas, sent by Sophia to him, because if he attempts to pocket the sum as he has done in the previous case, the matter will be unfolded; thus "by the friendly aid of fear, conscience obtained a complete victory in the mind of Black George". George's ingratitude to Tom is apparent, although Tom in return attempts to save his family from starvation.

In a further situation, the reader as much as Tom doubts George's behaviour on meeting Partridge in London and knowing that Bilfil is coming to town in pursuit of Sophia to marry her. Partridge in his course of conversation with George, hints at Tom's relationship with Bellaston and when Tom accuses Partridge of betraying him, he confirms George's loyalty: "I can assure you, George is sincerely your friend, and wished Mr. Bilfil at the devil more than once; nay, he said he would do anything in his power upon earth to serve you" (Fielding's Tom Jones, BK xv, Ch. 12, p. 737). Partridge seems to know little about George in comparison either with Tom or with the reader. George appears in a different air, near the end of the book. The reader seems to forgive him from his previous lapses, as when Tom has been imprisoned and George has been acquainted with reports among the Westerns, that Tom is about to be hanged; George appears of a "a compassionate disposition", rapidly offers services and money to Tom and quickly brings news about Sophia to Tom. Empson is puzzled by such narrative shift: "No doubt we are to believe the details, but Fielding still feels free, ... to give a different picture of the man's character at the other end of the novel; I take it be refused to believe that the "inside" of a person's mind ... is much use for telling you the reel source of his motives" (Empson, 1982, p. 135).

It is only through full cognizance of the inside of a person's mind, that one is being acquainted with that person's motives. The theme of the novel, however, suggests that the outward appearance of a person could lead to delusion and it is the prudence and the acute insight of the reader that unravel connotations. It is through reduced information that the reader makes evaluation; that is why Black George is seen in two contradictory extremes in the reader's eyes. Therefore, it is not the character of George, which changes but rather the reader's evaluation in the light of the given information that changes. Partridge is also introduced as flat character; at first he is seen as a learned, good-natured and a successful school master; “... tho' this poor men had undertaken a profession to which learning must be allowed necessary, this was the least of his commendations" (Fielding's Tom Jones, BK, 11, p. 91). The last sentence in the quotation maintains inherent meaning, either learning is among other professions that are worthy of commendation or his learning is terribly ranked. This irony, of course, does not reflect directly the narrator's view of Partridge. A little bit later, he is seen afraid of his wife. His motives when the reader has met him 
at Hambrook presents him in a different view, he wishes to accompany Tom in his military pursuit, in which, he sees an opportunity to persuade Tom to come back home in order to gain a reward from Allworthy. Later his cowardice is reaffirmed, when he is afraid to take part in the battle between Tom and Northerton to rescue Mrs. Waters. He is seen shivering on his knees, afraid of being shot by the highwayman. He is also afraid of a ghost, which has been participating in the performance of Hamlet.

A different presentation of Partridge is celebrated, suggesting that his probity and adherence to moral codes are not so far underscored. This presentation is maintained when he offers to borrow two horses from an inn, "now as the honesty of Partridge was equal to his understanding, and both dealt only in small matters, he would never have attempted a roguery of this kind, had he not imagined it altogether safe". In spite of Partridge's early presentation in the book, he is revealed to be neither honest, nor charitable, in addition to being a coward and an opportunist, who sees that accompanying Tom to convince him to return home, is a chance to win a reward from Mr. Allworthy. When Partridge realizes in London that Tom has entirely no money, he urges him to break his relationship with Sophia and return to Allworthy. Such an attitude does not suggest his selfish motives, as much as his good nature: “... that Partridge, among whose vices ill-nature or hardness of heart were not numbered, burst into tears; and after swearing he would not quit him in his distress, he began with the most earnest entreaties to urge his return home. "For Heaven's sake, sir', says he, 'do but consider ... How is it possible you can live in this town without money? Do, what you will, sir, or go wherever you please, I am resolved not to desert" (Fielding's Tom Jones, BK XIII, Ch. 6, p. 629).

Just as it is revealed late in the book that Black George has a "compassionate disposition", it is the same, that Partridge is not ill-natured or hard-hearted, but good natured as was proposed by the narrator, early in the book. The scenes, in which Partridge appears, shed no light on his good nature, as when he rejects to give a shilling to a lame beggar. He seems to be interested in financial affairs. He is desirous to know the amount of money given to Tom by Allworthy, and he is less inclined to extend his own money to Tom in an attempt, either to impel Tom to use Sophia's bank note or return home. A distinguishing feature of Partridge's character is feelings of devoted attachment and affection to Tom. He insists to keep by Tom's side, not merely for reasons of self-interest.

Described as 'faithful servant', Partridge was greatly frightened at not hearing from his master so long, when Tom has been put in jail for wounding Fitzpatrick. The narrator's earlier definition of Partridge and the reader's evaluation of him are discovered to be both inadequate. Partridge's dishonesty is rebuked in the reader's eyes, yet it is only in one instance that his dishonesty is praised; when he attempts to conceal the truth from Allworthy lest he knows that Tom and his mother have committed incest ignorantly. The label that suggests Partridge to be an 'honest fellow' does not strictly speaking suggest that he is honest, nor does it indicates him to be dishonest. Each case has its own justifications. The epithet 'honest fellow' resembles that given in the introduction, that he is 'one of the best-natured fellows in the world. The context emphasizes the opinion of the world rather than that of the narrator. The character of Partridge is displayed, to be neither so good, nor so bad. In both the cases of Partridge and Black George, there are inconsistencies; the characters are presented in a certain view, contrasted a little bit later by another appearance. However, the narrator aims at concealing information which influences the reader's judgment, and in the meantime exhibits new evidence which destablizes the reader's former response, suggesting inadequacy.
Nightingale who appears at the very end of the book is introduced as one of those "men of wit and pleasure about town", who devote their more serious hours to criticizing new plays, writing love poems, gaming, hack-writing and considering of methods to bribe a corporation". The narrator confirms that he was a modern fine gentleman "only ... by imitation, and meant by nature for a much better character". When the reader next meets him he is presented in a different air, seems to be a niggard. When Tom is acquainted with the terrible situation of Mrs. Miller 's cousins, he offers fifty pounds to relieve their distress, while Nightingale, not acquainted with Tom's offer, states, "I will give them a guinea with all my heart".

Nightingale's reluctance to extend money seems natural rather than deviation from the normal measure. The narrator points out that, there are those who consider charity something which deserves reward or praise, whatever the quantity of donation is, while, there are others who consider charity a duty which is either to be perfectly done or not at all. The narrator comments upon Nightingale's character: "This Nightingale, of whom we shall be presently obliged to say a little more, was in the ordinary transactions of life of a man of strict honour, ... he was even here as void of principle as gentleman sometimes are; ... but it is certain he had been guilty of some indefensible treachery to women, and had in a certain mystery called making love, practiced many deceits which if he had used in trade he would have been counted the greatest villain upon earth" (Fielding's Tom Jones, BK XIV, Ch. 4, p. 669).

Many ideas arise in the reader's mind as regards Nightingale's character; "a man of strict honour", "the greatest villain upon earth" "void of principle" and guilty of "indefensible treachery to women". "He intends to change his place of residence without taking leave from Nancy and he declares that he is innocent of any approaches to the girl, asserting to Tom, "what, do you suppose", that we have a bed together?" Shortly, afterwards, it has been discovered that he has been indeed in bed with Nancy and has deserted her pregnant with his child. Tom's persuasive arguments to Nightingale, probably have worked to stricken his conscience and to give him the chance to marry his own whore. Nightingale having his feelings awakened by Tom's eloquence, consequently declares his marriage with Nancy. Nightingale, has committed "indefensible" crimes with women, is not viewed in an incredible air to do so again. After being seen selfish, callous and degraded in the reader's eyes. Nightingale is redeemed by conciliating his affair with Nancy. Irony is suggested in a phrase proclaiming Nightingale "worthy young man"? If Nightingale is to be worthy, it is for his endeavors to collect evidence that will free Tom from prison and if he is ranked unworthy, it is for the fact that when the evidence goes against Tom, he begins to suspect Tom's story, telling him 'if you disguise anything to us; you will only be an enemy to yourself".

The concept of "chastity". The concept of chastity seems to be baffling in examination as much as the concept of charity. The narrator is aware to differentiate love from lust, thus allowing the reader to excuse the beahviour of some characters and denounce the behavior of others. Empson proposes that the reader may: "get to the point of reading Tom Jones with fascinated curiosity, baffled to make out what (the narrator) really does think about ... (among other things) the Christian command of chastity" (Empson, 1982, p. 124).

The narrator exploresthe wide meaning of love and gives an answer to those who ignore the existence of love. The difference between the narrator's own view of love and the meaning imposed on the word by custom is explored: "... what is commonly called love, namely the desire of satisfying a voracious appetite with a certain quantity of delicate white human flesh, is 
by no means that passion for which I here contend. This is indeed more properly hunger; and as no glutton is ashamed to apply the word love to his appetite, and to say he loves such and such dishes, so may the lover of this kind ... say, he hungers after such and such women" (Fielding's Tom Jones, BK VI, Ch. 1, p. 252). The narrator adds that love is opposed to hunger and is part and parcel of benevolence. The pure love is that which contributes to the happiness of others, and which is "sweetened by the assistance of amorous desires". Thus love is independent of sexual desires which are associated with hunger or more appetite. Sometimes, sexual desires become a part of love and thus they are excusable; but when they become a part of hunger or more appetite, they arouse contempt. The distinction between love and is set out in the example of Tom's love for Molly Seagrim, in comparison with his love for Sophia. Tom's love of Molly Seagrim is extended from his compassion for the situation of her family and from his gratitude for her interest in him in addition to his desire for her person. Tom seems to act neither for the mere appetite nor for exact love, which becomes clear when being aware of Sophia's affection for him. It is Tom's behavior towards Sophia and Molly which is to be investigated for determining the definition of love. Molly's love of Tom is not of that kind which could give him any feeling of discomfort at her faithlessness. Meanwhile, his love for Sophia is marked with "unbound passions".

Although Tom's emotions are wholly dedicated to Sophia and his affections for Molly are not greatly marked, yet he allows himself to be once again seduced by her, which is no more than a consolation for his quarrel with Bilfil and being drunk, and lonely for Sophia. He hardly loves Molly than she loves him: "Jones probably thought one women better than none, and Molly as probably imagined two men to be better than one" (Fielding's Tom Jones, BK V, Ch. X, p. 240). Jones retires into the bushes with Molly because one woman is better than none. Rawson suggests that Tom's love is the outcome of "appetite alone". The effects of appetite seem to align those of benevolence or pure love. The esteem and gratitude, Tom cherishes for both Molly and Sophia are the effect of his attraction to them. Attraction seems to encourage benevolence rather than the latter promotes the former, as being suggested by the essay on love. If love is incorporated with emotions which aim at the happiness of others, then Tom loves both Molly and Sophia. Molly is no more than a whore, like those who marry men whom they dislike and abhor, only for their fortunes. Fielding calls that kind of marriage 'legal prostitution for hire'. Molly's plan to deceive Tom by convincing him that he is the father of her bastard son, simply proceeds from her fear of losing her generous lover (Rawson, 1959, pp. 400-404). There are two kinds of appetite that are noteworthy; appetite that satisfies itself at any rate and appetite that could be kept under control when its satisfaction would probably cause the misery of others. Tom at the age of sixteen, when he casts eyes of affection on Molly, has been controlled by his principles from pursuing her: "To debauch a young woman, however low her condition was, appeared to him a very heinous crime" (Fielding's Tom Jones, BK IV, Ch. VI, p. 169).

There are some people who ignore the existence of love in the human heart and in the meantime, they are incapable of understanding benevolence, since they are only capable of mere appetite. "And love probably may, in your opinion, very greatly resemble a dish of soup". Mrs. Water's affection for Tom ranks her among those group of people: “... She was in love, according to the present universally received sense of that phrase, by which love is applied indiscriminately to the desirable objects of all our passions, appetites, and senses, and is understood to be that preference which we give to one kind of food rather than to another" (Fielding's Tom Jones, BK IX, Ch. V, p. 454). Later on the narrator presents Mrs. Waters in a different view, after being rescued by Tom from Ensign Northerton: "women to their glory be it spoken, are more generally capable of that violent and apparently disinterested passion of love, which seeks only the good of its object, than men. Mrs. Waters, therefore, was no sooner apprised of the danger to which her lover was exposed, then she lost every consideration besides that of his safety" (Fielding's Tom Jones, BK IX, Ch VII, p. 463). It is uneasy to bring to consistency, Mrs. Waters' goodness and her sexual freedom. She is Captain Waters' wife and has initiated a close acquaintance with Ensign Northerton, which has worked for the defamation of her reputation. Nothing dictates her conscience as long as, what satisfies her pleasures, does not harm anybody. Her benevolence which has been concealed, is unearthed when Tom is put in jail for wounding Fitzparick, with whom Mrs. Waters has kept company since their departure from Upton. Patridge realizes that Mrs. Waters resembles Benny Joes, as both see it natural to embark upon incest. Yet, it is the discovery that Benny and Mrs. Waters are the same person that adds irony to the matter. It is underlined that Allworthy's condemnation of Jenny Jones has been for her inability to preserve her chastity. "The heinous nature of this offence must be sufficiently apparent to every Christian inasmuch as it is committed in defiance of the laws of our religion, and of the express commands of Him who founded that religion" (Fielding's Tom Jones, BK 1, Ch. VII, p. 66).

The above mentioned extract includes the same lesson delivered to Jones when it has been hinted that he is the father of Jenny's bastard son. Despite, the exhortation and the moral lesson given by Allworthy to Tom and Jenny, neither of them seems to obey the exhortation nor respond to the lesson. Mrs. Waters, who has been described early in the novel as a 'slut' proves to be a truly benevolent character. Her sexual freedom which unquestionably lay emphasis for denouncing her, seems, after all, one of the elements which underscore her sympathetic nature and benevolence. The man to whom she owes happiness at Upton, is the men to whom she wishes happiness in the arms of another woman. Meanwhile, appetite is only blameworthy, when it impels one to sacrifice another's happiness to one's own. Bilfil's appetites which are, "the common property of all animals" represent such aspect. What is subject to condemnation, is Bilfil's sexual pursuit to Sophia which is heightened by her intense dislike of him, in addition to his thought of keeping Sophia away from Tom as a revenge on Tom's side, which is just a means of separating the two lovers. Tom, in the meantime, whose animal spirits are somewhat stronger than Bilfil's, vows to "sacrifice everything to the possession of my Sophia but Sophia herself". Speaking with Nightingale, Tom points out that chastity is not among his virtues and he admits "I have been guilty with women, I own it, but am not conscious that I have ever injured any-nor would I, to procure pleasure to myself, be knowingly the cause of misery to any human being". Clearly, Bilfil's attempt to establish his own happiness depends upon his desire to undermine the happiness of others, while, Tom's happiness could not be built by demolishing the happiness of others or causing misery to them. Remarkably, Lord Fellamar's tender feelings towards Sophia shares Bilfil's emotions. His affections towards Sophia also share the characterization of Tom's feelings towards Molly, "the nobleman ... might now without any great impropriety, be said to be actually in love with (Sophia)". Apart from Sophia's physical charms, Lord Fellamar states to Lady Bellaston, "I should swear she had been bred in a court; for besides her beauty, I never saw anything so genteel, so sensible, so polite" (Fielding's Tom Jones, BK XV, Ch. 2, p. 698).

A further distinction between Tom's feeling and those of the nobleman, Fellamar, is that Tom's life when discovering Sophia's passion becomes "a constant struggle between honour and inclination", while Fellamar's life becomes a struggle between 'honour and appetite'. Fellamar, at the beginning attempts to prove the success of honour, by approaching. Lady Bellaston and 
by rejecting the idea of rape, but when he is being accused by Lady Bellaston of lacking courage, he attempts rape as a point of honour and to prove himself a "man of spirit". Building his opinion on a false view of honour, Fellamar continues his relationship with Bellaston, because he feels himself owing much to her kindness. In this connection, Tom's binding emotions with Sophia, have resulted in reformation and wisdom: "The first moment of hope that my Sophia might be my wife, taught it me at once; and all the rest of her sex from that moment became as little the objects of desire to my sense, as of passion to my heart" (Fielding's Tom Jones, BK XVIII, Ch. XII, p. 866). Tom's love affair with all amours have something to do with the heart, including Lady Bellaston for she has secured him against starvation. Thus it is the calibration of the quantity of love, neither the kind of love, that strikes a difference between these amours and Tom's passion for Sophia. Chastity seems to suggest "rigid virtue" or excessive modesty incorporated under prudery. Chastity seems to be meaningless as being suggested by Fielding. Molly despite her unchastity seems to be likeable. Square, on the other hand, being an advocator of moral lessons, is degraded in the eyes of the reader for working in the opposite side to his advocacy and proving his weakness on attempting a sexual relationship with Molly. Moreover, Fellamar attempts rape, only to prove his manhood rather than to satisfy an appetite. Jonny Jones is seen in a view less strict than that presented by Allworthy.

The concept of "charity". In the early chapter in Tom Jones, Fielding's definition of charity aligns that which he has initiated in Joseph Andrews, indicating that deeds are underlined rather than dispositions. In the dialogue between Mr. Allworthy and Captain Bilfil, Bridget's husband, who has known that Partridge is Tom's father, it seems that the Captain attempts to decrease Allworthy's tender feelings towards the child, whom he regards a rival in his quest for Allworthy's fortune. He capitalizes on the chance for doing so through his discussion on the nature of charity: "The Christian religion, she said, was instituted for much nobler purposes than to enforce a lesson which many heathen philosophers had taught us long before ... (he said) ... a virtue much higher, and more extensive in its nature, than a pitiful distribution of alms, which ... could never reach many; whereas charity, in the other and truer sense, might be extended to all mankind" (Fielding's Tom Jones, BK II, Ch. V, p. 101). Bilfil further illustrates that the man who does help others materially is merely encouraging vice to triumph over virtue, as long as such aid is extended to those who do not deserve it. It is notably that Bilfil is talking about Partridge. Allworthy states that his ideas of charity "was interpreted to consist in action, and that giving alms constituted at least one branch of that virtue". According to Allworthy, charity is associated with the way that one diminishes the pressure of distress of another person, and it is by virtue of charity that "we condescend to share some part of them by giving what even our own necessities cannot well spare". Allworthy proclaims that a small number of cases which let man fall a prey to ingratitude from others or harden his heart against the distress of others cannot destabilize a truly good man from extending generosity to others, as long as "nothing less than a persuasion of universal depravity can look up the charity of a good man and 'surely it unfair to argue such universal depravity from a few vicious individuals" (Fielding's Tom Jones, p. 103).

Fielding also advocates that charity consists in the relief of suffering, which comes in line with the doctrines of the lowchurch. Although, the narrator assert that Allworthy is entitled to this virtue namely, charity, and despite the fact that, he fulfills his principles on an accurate basis, yet he is not sufficiently ranked as charitable as it first appears in the reader's mind. There are cases which reveal Mr. Allworthy less than completely generous. The first case is that which unfolds in the way he deals with Partridge. Being informed by Captain Bilfil about some aspects of Partridge's paternity, Mr. Allworthy questions Deborah Walkins who affirms the subject of debate. In a further stance, Partridge is proved guilty in the eyes of Mr. Allworthy despite Partridge's affirmation of his innocence. Mr. Allworthy is convinced by the indictment launched against Partridge by his wicked and wild wife concerning the fact; that Partridge is the father of one of the two bastards brought by Jenny Jones and thus, he decides to postpone judgment until Jenny can appear as a witness. On being informed that Jenny 'had left her habitation a few days before in company with a recruiting officer', Allworthy declares that she is no better than a "slut" whose word is not to be trusted and points out that if she says that truth then: "She must have confirmed what so many circumstances, together with his own confession, and the Declaration of his wife, that she had caught her husband in the act, did sufficiently prove" (Fielding's Tom Jones, BK II, Ch. VI, p. 107). According to such circumstances Partridge and his wife are deprived of much of their income which has been taken from their school. Allworthy has not shown callousness but rather intends to supply them with enough money upon which they could be able to subsist, yet on the death of Partridge's wife, he has left the country threatened with the danger of starving. The next time the reader meets Partridge is when Tom has encountered him at an inn working as a barber. The fate of Partridge has been unknown for the reader within a number of intervening years, until it is only unraveled in the end of the story. A wicked and vengeful neighbour has footmarks for foiling Partridge's expected success of another school and for being sent to jail for seven years, which are both attributed to the fact that Partridge's pig has intruded into that man's property. The magistrate, Allworthy, seems less interested in that issue in comparison with his anxiety to discover the true parentage of Tom, which is a mark of causal injustice. "Well", says Allworthy, 'pass that over till your return to England" (Fielding's Tom Jones, BK. XVIII, Ch. VI, p. 833).

The nature of Allworthy's compassion is also examined in the way he handles the issue of Black George. Tom has been seized in company with another man caught while venturing illicitly in squire Western's property and on being beaten mercilessly by Thwackum to learn the name of his companion, he is forced to divulge such secret and in that account Allworthy has dismissed the gamekeeper from his service. The justice of this sentence is enhanced by the information that "Mr. Allworthy had given the fellow strict orders on pain of forfeiting his place, never to trespasses on any of his neighbours" (Fielding's Tom Jones, BK III, Ch. II, p. 125). Tom assures that George's trespass or intrusion upon the property of squire Western is merely in response to his request and the shooting of the Partridge is migrated for the "covey was originally sprung in Mr. Allworthy's own Manor". As a result of George's dismissal from his service, he and his family, like Partridge, are left to suffer from starvation, it is only due to the good offices of Tom that they are rescued. When Tom manages to acquaint Allworthy of the miserable conditions of the poor family, Allworthy has given the mother "a couple of Guinee" to clothe her children and is convinced by Tom, that he has to think of any means, by virtue of which the family could subsist. Allworthy's good offices are demolished on being informed by Bilfil that the gamekeeper has illegally killed a hare belonging to Western to feed his family. Bilfil exaggerates George's transgression to Allworthy: "Bilfil ... considerably altered the story; for he said that George had wired hares. These alterations might probably have been set right, had not Master Bilfil unluckily insisted on a promise of secrecy from $\mathrm{Mr}$. Allworthy, before he revealed the matter to him; but by that means the poor gamekeeper was condemned without having an 
opportunity to defend himself" (Fielding's Tom Jones, BK. III, Ch. X, p. 148).

Once again Allworthy punishes a man on the basis of rumours and hearsay "... there is no zeal blinder ... against offenders" (p. 148). If the situation comments on Allworthy's attitude, it also reveals Bilfil's malice. The third case which unravel that Allworthy's compassion is controlled by his sense of justice, is his decision to turn Tom away. Such a horrible deed undertaken by Allworthy is the culmination of suspicions that Tom intends to steal Sophia from Bilfil, which are built on two extremes, namely, Squire Western's notice of Sophia's faint in Tom's arms and Mrs. Western's infringement of Sophia's trust. In addition to that Bilfil out of his malice and ill-intentioned purpose fabricates stories on Tom to distort his image before Allworthy. He has accused him of drinking intoxications during Allworthy's illness and in the meantime, he has claimed that Thwackum has discovered him in the bushes "engaged with a wench in a manner not fit to be mentioned" (Fielding's Tom Jones, BK. VI, Ch. X, p. 285). Allworthy maintains that man is guilty until proven innocent, and as long as Tom has been really drinking when he received the news of Allworthy's recovery, followed by the news of Bridget's death, he cannot conceal or deny the indictment levelled against him. Allworthy tells Tom, "that unless he could clear himself of the charge, he was resolved to banish him from his sight forever" (Fielding's Tom Jones, p. 286). He further illustrates that he has to act, as justice impels him to: "The world, who have already censured the regard I have shewn for you, may think, with some colour at least of justice, that I connive at so base and barbarous on action ... indeed equal to your crimes, and I can think myself justifiable in what I am now going to bestow on you" (Fielding's Tom Jones, BK. VI, Ch. XI, p. 287).

Allworthy afterwards dismisses Tom with a sum of money to start a new livelihood. The narrator comments on Allworthy's decision: "The Reader must be very weak, if, when he considers the light in which Jones then appeared to Mr. Allworthy, he should blame the rigour of his sentence. And yet all the neighbourhood, either from this weakness, or from some worse motive, condemned this justice and severity as the highest cruelty" (Fielding's Tom Jones, p. 288). The term "weak" or "weakness" in the above mentioned passage becomes associated with compassion. This, it is the neighbours' compassion which impels them to exaggerate Allworthy's cruelty towards Tom, disregarding to mention that he has been sent with five hundred pounds. The reader should not denounce Allworthy's decision as much as he has to find out reasons behind which he is forced to embark upon this step. First of all, Jones appears in a very bad position, and unfortunately the evidence is against him, thus, the decision for punishing him could not be rejected. On examining these three incidents, it is revealed that Allworthy's character is characterized with both a charitable nature and a sense of justice.

Although, sometimes he attempts hasty conclusions and gives an ear to hearsay and rumours, yet it is out of fear to encourage vice which projects him to such an attitude. It seems in the eyes of Allworthy, that it is better to give alms than to give one a good opinion. Being strict in judgement, followed by a decision to supply the family of the culprit with money to subsist for their life is merely to bring Allworthy's conscience to comfort and it is not an overall sign of his charitable nature. It is worthy to note, that, Bilfil's rejection to the idea of charity, which according to his own view is a means to assist the wicked and to allow vice to triumph over virtue, has actually influenced Allworthy's opinion and has urged him to treat Partridge, Tom and George on strict and severe bases. As long as, Allworthy sees that the three men he judges are unquestionably guilty, he regards it immoral to release them without punishment. Along with Allworthy's complete devotion to severe the basis of justice, there is a flaw in his character in my own view which makes him fall as a prey to deception from clever hypocritical and ostensible characters such as Bilfil who has managed to undermine Allworthy's benevolent impulses.

Judgement which is accompanied by mercy and compassion seems to be a difficulty for Fielding. Fielding sees to give a defense of Allworthy: "... the mercy may appear more amiable in a magistrate, severity is a more wholesome virtue; nay severity to an individual may, perhaps, be in the end the greatest mercy, not only to the public in general ... but to many individuals". A distinction is also drawn by Fielding as regards "the passions of the man" and the "principles of the magistrate", 'indicating that the latter should take priority over the former in cases of villainy. Probing the characters of Tom end Allworthy as judges is also the focus of excavation. The significant case of Tom's judgement is his meeting with the highwayman who has tried to rob him and Partridge, and on investigating his circumstances, it is unearthed that he is being stript out of his livery and it is the dire need to provide for his almost dead and starving family which forces him to attempt robbery. The highwayman suggests to take Tom to his house to prove the veracity of his story and he has highly agreed when Tom has accompanied him, that Tom no longer doubts him. Tom extends the poor man a couple of guineas as soon as he has felt pity for him. Tom giving the highwayman a sum of money to provide for his family, seems to follow the example of Allworthy giving Black George the same amount of money to serve his family. Similarity worked out by the attitudes of both Allworthy and Tom as regards their financial aid to the poor, seems to be disparity in their disposal, as the former provides money which is excessive to his needs, the latter grants money of which he is in dire need. Neither of these cases prove the extent of the culprit's guilt, yet the judges are ruled by different dispositions.

The narrator seems to probe Tom's aid to the poor within the context of charity: "Our readers will probably be divided in their opinions concerning the action (i.e. Tom's charitable treatment of the highwayman. Some may applaud it perhaps as an act of extraordinary humanity, while those of a more saturnine temper will consider it as a want of regard to that justice which every man owes his country" (Fielding's Tom Jones, BK XII, Ch. XIV, p. 805). Irony is indicated in the phrase "those of a more saturnine temper" which represents hard-hearted and callous people. Tom seems to be encouraging a criminal, namely, the highwayman, as long as he rejects to verify his story. Tom's act, besides being a sign of a compassionate nature is also a mark of disregard to the strict laws of justice. Condemning or applauding such an act, mainly depends on one's own view whether to stand by the side of the society or the individual.

On drawing up a comparison between Allworthy and Tom, it is clear that Allworthy's handling of the matters is different from Tom, but this is due to the fact that he is being a magistrate shouldering a responsibility which is not borne by Tom. It is the duty of Allworthy to settle or resolve his judgment for the benefit of the society and it is his zeal for justice which does not allow his benevolent impulses to affect his judgment. Two further attitudes reflect the different perspectives of Tom and Allworthy. The first mirrors Tom's extreme forgiveness which is seen by Allworthy as "mistaken mercy". When Allworthy is acquainted with Bilfil's evil deeds, it is Tom, the victim of Bilfil's attempts, who initiates to reconcile between Allworthy and Bilfil. Tom says: "Let me beseech you; sir, to do nothing by him in the present height of your anger. Consider my dear uncle, I was not myself condemned unheard" (Fielding's Tom Jones, BK XVIII, Ch. XI, p. 859). Allworthy's attitude towards Bilfil is hardened and not reconciled by Tom's forgiveness: “... do not flatter him with any hopes of my forgiveness; for I shall never forgive villainy farther than my religion obliges" (Fielding's Tom Jones, p. 861). Tom also 
attempts to extend monetary aid to Bilfil and promises to help him to be reconciled with Allworthy. It is worth pointing out, that Allworthy is willing to forgive, only in fulfilment of the religious principles, while Tom who is really harmed by Bilfil, is ready to help and most charitable from the depth of his heart. The second attitude is marked by Tom's shock at the news of Black George's theft of the sum of money which Allworthy has given Tom on his departure. Tom for the second time shows no rancour, indicating that George has extended an amount of the sum to him, yet Allworthy could not bear that, saying that it is too much: "Child, cries Allworthy, 'you carry this forgiving temper too far. Such mistaken mercy is not only weakness, but borders on injustice, and is very pernicious to society, as it encourages vice" (Fielding's Tom Jones, p. 862).

The concept of charity is complicated by the two above mentioned scenes. The question is, whether mercy, compassion, and forgiveness contradict justice or not?; Whether compassion mercy and forgiveness are virtues or vices? or whether they cause harm or reconcile? Tom's attitude seems to be mostly Christian. Although the reader admires his generous spirit, yet it is not concluded that his ethical standard is the ultimate measure for trespasses launched by some against others. It is right that Tom forgives and in the meantime it is right that the culprit gets his deserts. A pressing problem imposes itself, while the religious doctrine asks for forgiveness, the laws of justice ask for punishment (see Haverkate, 1990; Glucksberg, 1995; Carston, 1981; Chen, 1990; Jorgensen et al., 1984; Williams, 1984; Barbe, 1995).

A further sign of Tom's charity, especially towards Bilfil, is his refusal to inform Bilfil of Allworthy's decision to dismiss him, because in his own view, this information would be an insult worse than Bilfil's crimes: "fortune may tempt man of no very bad depositions to injustice, but insults proceed only from black and rancorous minds, and have no temptations to excuse them" (Fielding's Tom Jones, BK VIII, Ch. XI, p. 859). Allworthy seems to accept Tom's forgiveness of George, much more than his forgiveness of Bilfil. To leave Bilfil without punishment is mistaken mercy and pernicious to society, as long as it encourages vice. Those who attempt to be charitable will run the risk of encouraging vice and diverging the laws of justice. On the other hand, if they attempt to fulfill the obligations of justice, they might be condemning others. Thus in neither cases, they have no confirmation of judging correctly, since the evidence is not sufficient to convey the truth. The difficulty appears in being both a Christian and a social man. Since judgment represents a vital importance, a judge has to collect all information possible and be careful of issuing hasty and rapid sentence. All people play the role of magistrates, either judging others or being themselves subject to judgement. A judge has to work in accordance with the laws of the religious doctrine and the laws of man.

A political reading of Tom Jones: Fielding as a political operative. At present, there are a number of political readings of Tom Jones (See Campbell, 1995; Stevenson and Paulson, 2000; Stevenson, 2005; Carlton, 1988; Brown, 1997; Downie, 2009; Schmidgen, 1992; Shanley, 2007). Fleming (2019, p. 662) argues that 'by recognizing the political significance of Sophia's muff, as both a body part and an accessory, we can demystify Fielding's infamous muff jokes and appreciate their relationship to the novel's setting, an event grounded in decades of debate about sex right and political right: The Jacobite Rebellion of 1745. The London in which Fielding spent most of his life was a world of literary and political ferment, an age of factionalism in the arts, with the Tory Wits (Jonathan Swift, Alexander Pope, John Gay, John Arbuthnot) allied against Colley Cibber, the poet laureate and self-proclaimed literary spokesman for the British Isles. It was a time, also, of great political controversy, with the ongoing conflicts between the Tories and Jacobites about the questions of religion and succession. These various sources, influences, and beliefs are molded into coherent works of art through Fielding's narrative technique. It is through the role of the narrator that he most clearly and successfully experiments in the methods of teaching a moral lesson.

Muffs first appeared on the arms of eminent courtesants in Venice in the fifteenth century, and this accessory arrived in England, by way of France, around 1572 (Chirman-Campbell, 2013, p. 134). Since their invention, muffs have been political, enmeshed in a nexus of capitalism, nationalism, and gender politics. In addition to operating as a visual sign, deploying 'muff' as a slang term had political implications (see Emberley, 1988; Wallace, 1997). The two dominant usages of 'muff as a slang term are: (1) 'muff' describes the entire genital area of a woman or (2) when coupled with other objects, it describes the penetration of a vagina. In both, the materiality of the female body and the materiality of the accessory are conflated to produce the double meaning (Fleming, 2019, p. 668). The muff became one of the most popular metonyms in the period (Wallace, 1997).

In her article, "The Politics of Sophia Wester's Muff", Fleming (2019, p. 659) examined Fielding's jokes about Sophia's muff in Tom Jones in relation to the novel historical context: the Jacobite Rebellion of 1745. First, she complicated earlier readings by scholars who have argued that the government of Sofia is an allegory for the government of the nation. Second, she traced how the embedded it-narrative of the muff figures Sophia's marriage contract as an analogy for the social contact, one that considers whether government should be decided by paternal authority or consent of the governed. Sophia's muff foregrounds this analogy and the novel's political allegory because muffs, as references to vaginas, metonymize the body part that determined how monarchies, money, and property were transferred. Third, she examined how Fielding's muff jokes directly engage with the fundamental question posed by the Jacobite rebellions: which family has a better right to inherit the crown, the Stuarts or the Hanover's?

Fleming (2019, p. 659) made it clear that 'even though Henry Fielding might be the most famous muff joke artist in the British canon, scholars have been dancing around the meaning of Sophia Western's muff in a carefully orchestrated minuet of avoidance for the least one hundred years. She, also, made two points clear; first, every work of printed scholarship employs euphemisms or circumlocutions when discussing Sophia's muff. Second, "our hesitation to openly discuss how Fielding repeatedly jokes about the penetration of a women's vagina in 'Tom Jones' keeps us from seeing that each muff joke carries significant political implications.

According to Johnson (1959, p. 690), the muff is a 'love token' between Sophia and Tom, acting as a substitute for the other person. De Ritter (1989, p. 44) argued that the muff was a tool that helped Tom to monitor his behavior and 'to devote himself more consciously to the woman he betrayed (Sophia Gee, 2010, p. 141) described the muff as a metonym, or a "prop", for the absent lover in the text. Engel (2015, p. 11) wrote that Sophia's muff invites sexual analogies (see Glover, 2006; Keller, 2007). In this regard, Pateman (1988, pp. 88-89) points out that when we read Fielding's novel, we continue to 'separate sex-right from political right. More specifically, Pateman (1988, p. 2) argued that the social contract is shaped by the sexual contract. The relationship between a man and a woman is made possible by 'sex right', which is a combination of men's 'political right' over women and sexual access to their bodies. Political theorists in the seventeenth century, according to Pateman (1988), distinguished between the 
power of the government over a subject and the power of a husband over his wife by arguing that 'women's subjection to men was natural. In this connection, Fleming (2019, p. 661) argues that regardless of natural subjection, women were political actors because of their "muffs", and the muffs women wore wielded political influence too. Relatedly, Pateman (1988, p. 371) points out that natural subjection was a fiction designed to explain women's absence from government institution: it insisted on women's natural incapacity for political life:

Women were incorporated into political order and not merely excluded (or left in the 'state nature', but their manner of incorporation was different from that of men (p. 370).

Fielding relies on the double meaning of the word "muff"slang for genitalia-to place his marriage as social contract analogy into the novel. Every vignette in the history of Sophia's muff dramatizes the question of Sophia's consent and engages with these competing theories of government by debating who owns Sophia's muff(s): Western the Jacobite, Tom the Hanoverian, or Sophia herself. By using a metonym for sex tight to discuss political right, Fielding broadens the contract analogy into an allegory designed to dissuade his readers from what he considers to be the egregious arguments of Jacobitism (Fleming, 2019, p. 664).

As Coley (1987) points out, Fielding, as a political operative who wrote anti-Jacobite pamphlets for the Hanoverian government, was highly aware that Jacobites used accessories to express their loyalty to the Stuarts. Jacobitism in England was, for the most part, dependent on a clandestine material culture: "Material culture seems to have been perceived by Jacobite publicists as being more 'real' than abstractions: expressed in mind or print: truth in things reflected truth in Kings. Jacobites stored their political truth in tangible things" (Guthrie, 2013, p. 39). In Tom Jones, Sophia's muff refers to something other than a fashion accessory, and it is the reference to women's genitals that is politically significant (Pittock (2013, p. 26). According to Fleming (2019, p. 669), Muff jokes carry with them the legal symbolism of property settlements, in which vaginas determined the conveyance of property, money, and on a grander scale, the monarchy.

Fielding's jokes about Sophia's muff engage with this legal authority to convey property through their double meaning. In the muff's first appearance, Fielding linguistically renders it a vagina. Sophia's vagina, that which cannot be openly referred to according to social convention, is "implied by" her accessory on the page (Wall, 2006, p. 133). Fleming (2019, p. 670) argues that Fielding employs the slang usage predicted on hands to turn the accessory into a metonym for Sophia's vagina. Sophia is depicted as part thing and her muff as part person when Tom "put his Hands into it" and "kept his Hand in". Tom describes Sophia as having "the prettiest Muff in the World": his fascination with the muff hinges on her body and her body's legal power. Indeed, the novel's first muff joke consists of a man who cannot inherit property according to common and ecclesiastical law holding a piece of property in his hands that is a metonym for the very thing that determines the conveyance of property. It is significant that neither the charms of Sophia's mind nor her beauty have an impact on Tom, but her muff does. In addition to this narrative purpose, Sophia's muff fulfills a political purpose in Tom Jones. Blackwell (2007, p. 289) argues that it-novels about shoes, coats, banknotes, and corkscrews represent prostitutes through metonymy. The embedded it-narrative of Sophia's muff achieves a similar effect. Fielding uses the muff to represent not the decreasing value of courtesans' bodies in circulation, but the value attached to a woman's reproductive capacity and her ability to transfer property to the next generation.
In conclusion, the linguistic gymnastics that muff jokes perform to elicit laughter are indicative of a culture that understands women as simultaneously persons and things. As Fleming (2019, pp. 679-680) points out, in the eighteenth century, muff jokes are only funny when they consciously display and play with two different types of property: women-asproperty and accessory-as-property. Their comedy speaks to a legal system that shifted between viewing women as persons or things, as proprietors or as vehicles of property transfer, depending on what was best for the court, the estate, or the monarchy. Fielding's muff jokes illustrate this broader political significance, as they rely on the muff s ability to metonymize both types of property: women and accessory:

We, as critics, should continue to illuminate women's covert contributions to eighteenth century British politics, regardless of whether they were made in a bedchamber or on a battlefield (Fleming, 2019, p. 680).

\section{Conclusion}

Fielding has proved himself not only a successful eighteenth century novelist, but also a master-key to the English novel at large. His capacity as a writer proves that he has abundant knowledge and skills not only revealed in the field of artistic activities, but also in fields of education, social classes "high and low people", law and religious affairs. Such skills and knowledge have enabled him to set up a panoramic view of English life with consummate excellence and success. Most of the delight and success in Fielding's Tom Jones are taken from the power of the narrative voice; the true representation of the English life in the eighteenth century with examples of high and low characters, the well-formed structure of the book, the picaresque elements and various coincidences which enhance the plot and add to the comic features exploited in the novel. Fielding's insistence upon depicting affectation which stems from hypocrisy, probably attempting to deceit and vanity, possibly akin to ostentation is a device to expose vice and ugliness on one hand and virtue and goodness on the other. Such device does not only invite the reader to judge these traits only in the characters but also to explore them in human nature as well as in the depth of his own nature.

Tackling the concept of the point of view in a literary work, Lang (1983) says that it deals with the extent with which the author's personality affects a literary composition. The author may behave as a teller, directly addressing the reader and asking questions. He may announce his presence through one of the characters of the artistic activity or through an exposure of an autobiographical experience. The author may also behave as an objective narrator. Fielding is an intrusive author and intrusive authors at large do not only present an artistic work but also interpret it. Intrusive authors declare their presence directly in an artistic formation. Fielding in Tom Jones underscores the omniscient narration, referring to characters either by their names or by the pronouns "he, she and they". Fielding through the digressive tales of the two books has managed to employ the first person narrative viewpoint within the framework of an exterior third person narration. It is through the omniscient narration that the author employs an intrusive narrator who is regarded as an authoritative capacity over the fictional world, commenting on the characters' behavior and attitudes.

It is through the narrative devices that an author incorporates biographical or autobiographical narrative forms and such works which have to do with the real world are didactic.

Arguments have been launched to differentiate between narration and description, yet it has been revealed that narration and 
description are not discriminated and both are placed under the genre of narrative. Through the narrative stratagems, Fielding conveys didactic lessons in an attempt to force the readers to adopt a sound judgment about the actions and the characters. Such didactic lessons set out a question about the extent to which education affects one's character. It has been made clear that there is no educational determinism theory, but is one's character built independent of education and is it only affected by the innate qualities or does education also affect one's character? It is the reader's role to comprehend the lessons directed to him. In case that the reader is being able to disclose the hidden reality of the text, then he will also be able to unveil the concealed reality of himself. Fielding's Joseph Andrews and Tom Jones reveal their aspects through sets of negations which stimulate the reader to pass through the perplexed norms to form a convincing view of the presented material. The negative form sets up a contrast that brings about these perplexing norms which in their turn set out an explicit understanding of the depicted idea.

Fielding extends the role of the narrator in Tom Jones, as teller of the tale, as moral guide, and as literary commentator and critic. Each of these voices was heard in Joseph Andrews, but here they come together in a unique narrative persona. Adopting the role of the stagecoach traveler, the narrator speaks directly to his fellow passengers, the readers. He is free to digress and comment whenever he feels appropriate, and there is, therefore, no need for the long interpolated tales such as appeared in Joseph Andrews. To remind his readers that the purpose of fiction is aesthetic as well as moral, the narrator often comments on literary topics: "Of the Serious in Writing, and for What Purpose it is introduced"; "A wonderful long chapter concerning the marvelous"; "Containing instructions very necessary to be perused by modern critics". Most important, Tom Jones demonstrates Fielding's skill in combining his moral vision with aesthetic form in a way that is most pleasurable to the reader. The reader learns how to live the good Christian life because Tom learns that lesson. Far more effective than parody, sermon, or moral exemplum, the combination of narrative voice and literary example of plot and character is Fielding's greatest legacy to the novel.

The structure of Tom Jones is based on the secularization of the spiritual pilgrimage. Tom must journey from his equivocal position as foundling on the country estate of Squire Allworthy (Paradise Hall) to moral independence in the hellish city of London. He must learn to understand and control his life. When he learns this lesson, he will return to the country to enjoy the plenitude of paradise regained that providence allows him. He must temper his natural, impetuous charity with the prudence that comes from recognition of his own role in the larger social structure. In precise terms, he must learn to control his animal appetites in order to win the love of Sophia Western and the approval of Allworthy. This lesson is rewarded not only by his gaining these two goals, but also by his gaining the knowledge of his parentage and his rightful place in society. He is no longer a "foundling". Tom Jones adapts the classical symmetry of the epic in a more conscious and precise way. The novel is divided into eighteen books. Some of the books, such as 1 and 4, cover long periods of time and are presented in summary form, with the narrator clearly present; others cover only a few days or hours, with the narrator conspicuously absent and the presentation primarily scenic. The length of each book is determined by the importance of the subject, not the length of time covered.

The books are arranged in a symmetrical pattern. The first half of the novel takes Tom from his mysterious birth to his adventures in the lnn at Upton; the second half takes him from Upton to London and the discovery of his parentage. Books 1 through 6 are set in Somerset at Squire All Worthy's estate and culminate with Tom's affair with Molly. Books 7 through 12 are set on the road to Upton, at the Inn, and on the road from Upton to London; the two central books detail the adventures at the Inn and Tom's affair with Mrs. Waters. Books 13 through 18 take Tom to London and begin with his affair with Lady Ballston.

Fielding's Tom Jones, which is built on satire, tackles also two important concepts namely, charity and chastity, and it is through connotations of meaning that the author makes it difficult for the readers to make a simple judgment and thus complications arise for the evaluation of characters. Some puzzling questions are set up; do mercy, compassion and forgiveness contradict justice or not? But whether they contradict justice or whether they do not, are they regarded as virtues or vices? Do mercy, compassion, and forgiveness cause harm or reconcile? The problem is incorporated in the fact that the Christian religious doctrine asks for forgiveness, while the laws of justice ask for punishment; a culprit should get his deserts. The problem is also incorporated in the fact that it is difficult to know which cases deserve forgiveness and compassion and which do not. Those who wish to be charitable with either encourage vice and infringe the laws of justice or fulfil the laws of justice and condemn others. In both cases, no assertions of judging correctly are underscored as long as the evidence is not sufficient to communicate the truth. A judge has to avoid hasty judgment as long as judgment constitutes a major significance. He has to judge not only in accordance with the laws of justice but also in accordance with the laws of the religious doctrine.

Irony as one of the distinguished devices exploited in Tom Jones, mainly unravels connotations of meanings and the nature of the characters. Irony in the limited sense of the word is relevant to the use of words for conveying the opposite of their literal meaning; or it might be identified as an expression or utterance marked by a deliberate contrast between apparent and intended meaning. The aim behind these contrasts of meaning is to initiate humours or rhetorical effects. It might be notable as well that incongruity arises between what might be expected and what actually occurs. Fielding's target for fully exploiting the device of irony in Tom Jones is to delineate characters' behavior and conduct. Fielding's technique sheds light on the significance of irony end underlines the fact that language is not merely an inflexible conveyer of information but rather the reader's mind has to be more flexible end capable of grasping shades of meaning. Fielding's technique of irony also destabilizes the reader's assurance of his unscrutinized notions. It is the attitudes of the reader as much as those of the characters that are being subject to examination by the novelist (see Le Boeuf, 2007; Gibbs, 1994; Attardo, 2000; Chen, 1990; Barbe, 1995; Kruez and Roberts, 1993; Clark and Gerrig, 1984).

The presentation of characters and the irony maintained in the book is not the ultimate investigation, but the narrative role and the narrator also contribute to the bulk of the whole work. Irony becomes apparent when the book is re-read and the enjoyment of re-reading the book is not only in questioning and doubting attitudes or disagreeing with assertions or generally accepted conclusions but also in being acquainted with the applied narrative stratagems and the narrator's role which works in a twoway track; creating puzzling characters and functioning in a puzzling way. Authors and readers are not the only characters taking part in a fictional work, but rather narrators play a pivotal role in the discourse of fiction. However, the narrative devices in Fielding's Tom Jones, vary from the first person narration to the third person omniscience stratagem. Fowler (1971) points out that Fielding chooses the 'I figure' especially in the interpolated tales to give himself the opportunity of speaking out his own viewpoint and addressing the reader directly to make this activity the focus of importance. Fielding also attempts to follow the path of the historian who keeps himself detached from the text. He maintains the principle of objectivity and asserts his role as 
selector and organizer. Commenting on the objective type of narration in Fielding's work, Leech (1981) that the significance of employing the third person is to undermine the part of the addressor in the novel's discourse so as to combine the parts of the implied author and narrator together.

The two major constants in Fielding's writing are the attempt to define a good, moral life, built on benevolence and honor, and a concern for finding the best way to present that definition to the reader. Thus, the moral and the technique can never be separated in Fielding's works. Joseph Andrews and Tom Jones bring together these two impulses in Fielding's most organically structured, brilliantly characterized, and masterfully narrated works. These novels vividly capture the diversity of experience in the physical world and the underlying benevolence of natural order, embodying them in a rich array of the ridiculous in human behavior. Fielding combines a positive assertion of the strength of goodness and benevolence (demonstrated by the structure and plot of the novels) with the sharp thrusts of the satirist's attack upon the hypocrisy and vanity of individual characters. These elements are held together by the voice of the narrator-witty, urbane, charming -who serves as moral guide through the novels and the world. Thus, beyond the comic merits of each of the individual novels lies a collective sense of universal mora] good. The voice of the narrator conveys to the reader the truth of that goodness. Although in Tom Jones Fielding still schematically associates characters with particular moral values, the range of characters is wider than in his previous novels. Even a minor character, such as Black George, has a life beyond his moral purpose as representative of hypocrisy and self-serving

\section{Data availability}

This study is an analysis of Henry Fielding's Tom Jones, ed. R.P.C. Mutter, England: Penguin Books Ltd, 1966.

Received: 6 December 2020; Accepted: 21 June 2021;

Published online: 12 July 2021

\section{References}

Alderson C (2000) Assessing reading. CUP, Cambridge

Allot M (1959) Novelists on the novel. Routledge, Kegan Paul, London

Alter R (1964) Rogue's progress: studies in the Picaresque novel. Harward Univ. Press, Cambridge

Amante D (1981) The theory of ironic speech acts. Poet Today 2(2):77-96

Apostoli P (2004) The European itinerary of the Picaresque novel and its traces in $19^{\text {th }}$ century Greek Literature: transformation and continuity. Neohelicon 31 (2):53-61

Ardila J (2010) Introduction: transational Picaresque. Philol Q 1:42-59

Ardila J (2015) The Picaresque Novel in Western Literature: from the sixteenth century to the Neopicaresque. Cambridge University Press, Cambridge

Attardo S (2000). Irony as relevant in appropriateness. J Pragmat 1:793-826

Barbe K (1995) Irony in context. Benjamins, Amsterdam

Bates E (1987). Language acquisition and language breakdown from a functionalist perspective. University of California

Battestin M, Battestin R (1989) Henry fielding: a life. Routledge, London

Battestin M (1959) The moral basis of fielding's art: a study of Joseph Andrews. Wesleyan University Press, Middletown

Berelson B (1952) Content analysis in communication research. Free Press, New York

Blackwell B (2007) Corkscrews and courtesans: sex and death in circulation novels. In: Blackwell $M$ (ed) The secret life of things: animals, objects and itnarratives in eighteenth-century England. Bucknell University Press, Lewisburgh, p. 289

Birke D (2015) Author, authority and authorial narration: the eighteenth-century English Novel as a Test Case. In: Birke Dorothee, Koppe Tilmann eds Author and narrator: transdisciplinary contributions to a narratological debate. De Gruyter, Berlin/Boston, pp. 99-111

Boisvert D, Thiede R (2020) Language, mind, and power. Routledge \& CRS Press Booth W (1974) A rhetoric of irony. Chicago University Press, Chicago
Brown G, Yule G (1983) Discourse analysis. Cambridge University Press, Cambridge

Brown H (1997) Institutions of the English novel: from Defoe to Scott. University of Pennsylvania Press, Philadelphia

Brown G (1983) Discourse analysis. Cambridge University Press, Cambridge

Brown RLJ (1980) The pragmatics of verbal irony. In: Roger W, Shuy, Shnukal Anna eds. Language use and the uses of language. Georgetown University Press, Washington, pp. 111-127

Busha C, Harter S (1980) Research methods in librarianship: techniques and interpretation. Academic Press, New York

Campbell J (1995) Natural masques: gender identity in fielding's plays and novels. Stanford University Press, Stanford

Campbell J (2005). Fielding's style. ELH 72. The Johns Hopkins University Press, pp. $407-428$

Campbell S, Roberts C (2007) Migration, ethnicity and competing discourse in the job interview: synthesizing the institutional and personal. Discourse Soc 18 (3):243-271

Carlton P (1988). Tom Jones and the '45 once again. Stud Novel 20(4) https://www. jstor.org/stable/29532597

Carston (1988). Language and cognition. In: Newneyer F (ed), Linguistics: the Cambridge survey, vol 3: Language: psychological and biological aspects. Cambridge University Press

Carston R (1981) Irony and parody and the use-mention distinction. Nottm Linguist Circ 10(1):24-35

Carter R (1986) A Question of interpretation: an overview of recent developments in stylistics. In: Theo D'haen ed Linguistics and study of literature. Rodopi, Amsterdam

Carter R (2010). Methodologies for stylistic analysis: practices and pedagogies. https://teach-grammar.com/wp-content/uploads/26-3-2021

Cavanagh S (1997) Content analysis: concepts, methods and applications. Nurse Res 4:5-16

Chapman R (1973) Linguistics and literature. Edward Arnold Publishers Ltd, London

Chen R (1990) Verbal irony as implicature. Unpublished PhD Dissertation, Ball State University, Muncie

Chirman-Campbell K (2013) He is not dressed without a muff: muffs, masculinity, and la mode in English Satire. In: Mansfield ElizabethC, Malone Kelly ed. Seeing satire in the eighteenth century. Voltaire Foundation, Oxford

Chomsky N (1965) Aspects of the theory of syntax. MIT Press, Cambridge, MA

Chomsky N (1968) Language and mind. Longman, New York

Clark H, Gerrig R (1984) On the pretense of irony. J Exp Psychol Gen 113 (1):121-126

Claude R (ed.) (2007) The Cambridge companion to Henry Fielding. Cambridge University Press, Cambridge

Coley W (1987) The true patriot and selected writings. Wesleyan University Press, Middletown

Cook G (1994) Discourse and literature. OUP, Oxford

Cook G (2000) Language play, language learning. OUP, Oxford

de Beaugrande R (1980) Text, discourse and process. Longman, London

de Beaugrande R (1984) Text production. Ablex, Norwood

de Sola Pool I (1959) Trends in content analysis. University of Illinois Press, Urbana

Downe-Wamboldt B (1992) Content analysis: method, applications and issues. Health Care Women Int 13:313-321

Downie J (2009) A political biography of Henry Fielding. Pickering \& Chatto, London

Eisenberg D (2018). Does the Picaresque novel exist? https://www.researchgate.net. publicaiton/238690386

El-dali H (2011) Meaning in language use: reflections from pragmatics and discourse analysis with special reference to political discourse. Ann Arts Soc Sci 32:5-77

El-dali H (2012). Narration and persuasion in English by Arabic and Spanish speakers. Lambert Academic Publishing, pp. 1-154

El-dali H (2019a) Language of consumer advertising: linguistic and Psychological perspectives. Stud Linguist Lit 3(2):95-126

El-dali H (2019b) Perfecting the theory of meaning: the story of pragmatic and discourse analyses. Adv Soc Sci Cult 1(1):50-89

Elo S, Kyngäs H (2008) The qualitative content analysis process. J Adv Nurs 62:107-115

Emberley J (1988) Venus and furs: the cultural politics of fur. I.B. Tauris, London Emden C, Hancock H, Schubert S, Darbyshire P (2001) A web of intrigue: the search for quality in qualitative research. Nurse Educ Pract 1:2014-211

Empson W (1982) Tom Jones. In: Paulson Ronald ed. Fielding: a collection of essays. Prentice Hall Inc, Hoboken, pp. 123-145 
Engel L (2015) Austen, actress, and accessories: much ado about muffs. Palgrave Macmillan, New York

Evans B (2018). Language, society and power. Routledge \& CRS Press

Fairclough N (1992) Language and power. Longman, London

Fleming K (2019) The politics of Sophia Western's Muff. Eighteenth-Century Fict 31(4):659-680

Fong Ha J, Anat D, Longnecker N (2010) Doctor-patient communication: a review. Ochsner J 10:10-38

Fowler R (1971) The languages of literature. Routledge \& Kegan Paul, London

Freeman D (1970) Linguistic approaches to literature. In: Freeman DonaldC ed. Linguistics and literary style. Holt, Rinehart and Winston Inc, New York

Gee S (2010) Making waste: leftovers and the eighteenth-century imagination. Princeton University Press, Princeton

Georgakopoulou A, Goutsos D (1999). Discourse analysis: an introduction. Edinburgh University Press

Gibbs R (1994) The poetics of mind. Cambridge University Press, Cambridge

Giora R (1995) On irony and negation. Discourse Process 19:239-264

Giora R (1997) Understanding figurative and literal language: the graded salience hypothesis. Cogn Linguist 7:183-206

Giora R, Fein O, Schwartz T (1997) Irony: graded salience and indirect negation. Metaphor Symbol 13(2):83-101

Glover S (2006) Engendering legitimacy: law, property and early eighteenthcentury fiction. Bucknell University Press, Lewisburg

Glucksberg S (1995) Commentary on nonliteral language: processing and use. Metaphor Symbol Activity 10(1):47-57

Guthrie N (2013) The material culture of the Jacobites. Cambridge University Press, New York

Hall G (2005) Literature in language education. Palgrave, London

Halliday M (1978) Language as a social semiotic: the social interpretation of language and meaning. Edward Arnold, London

Hammudin B (2012). A comparative study of politeness strategies in economic journals. Doctoral dissertation, University of Malaya

Hardavella G, Aamli-Gagnat A, Frille A (2017) Top tips to deal with challenging situations: doctor-patient interactions. Breathe 13:129-135

Harris S (1952). Evasive action: how politicians respond to questions in political interviews. In: Scabbell P (ed) Broadcast talk. pp. 76-99. London: Sage, 1991

Hart C (2020). Researching discourse: a student guide. Routledge \& CRS Press

Hatfield G (1968) Henry Fielding and the language of irony. University of Chicago Press, Chicago

Haverkate H (1990) A speech act analysis of irony. J Pragmat 14(1):77-109

Hsieh H-F, Shannon S (2005) Three approaches to qualitative content analysis. Qual Health Res 15:1277-1288

Hume R (2010). Fielding at 300: elusive, confusing, misappropriated, or (perhaps) obvious? The University of Chicago

Hutchens E (1965). Irony in Tom Jones. Quoted from "The Aspect of Language and Style in Henry Fielding's Novels", an unpublished PhD Dissertation by S. M. Abdel Latif. University of Chesterfield, England, 1983. University of Alabama Press

Iser W (1978) The implied reader. The Johns Hopkins University Press, Baltimore \& London

Jakubjakova, M (2017). The history of Tom Jones: a foundling as a Picaresque Novel. https://www.researgate.net.publicaition/320267841

James H (1968) The Princess Cassamassima. Harper \& Row, New York

Johnson L (2002) Meaning and speech act theory. University at Buffalo, New York

Johnson M (1959) The device of Sophia's Muff in Tom Jones. Modern Language Notes 8:74, https://www.jstor.org/stable/3040386 https://www.jstor.org/ stable/3040386

DeRitter J (1989) How came this muff here? a note on Tom Jones. English Language Notes 26(4):44

Jorgensen J, Miller G, Sperber D (1984) Test of the mention theory of irony. J Exp Psychol 113(1):112-120

Keller E (2007) Generating bodies and gendered selves: the rhetoric of reproduction in early modern England. University of Washington Press, Seattle

Kreuz R, Roberts R (1993) In satire and parody: the importance of being ironic. Metaphor Symb Activity 8:97-109

Kreuz R, Glucksberg S (1989) How to be sarcastic: the echoic reminder theory of verbal irony. J Exp Psychol 118(4):374-386

Krippendorff K (2004) Content analysis: an introduction to its methodology. Sage Publications, Beverly Hills

Lang B (1983) Philosophy and the art of writing. Bucknell University Press, Lewisburg

Le Boeuf M (2007) The power of ridicule: an analysis of satire. Sr Honor Proj 63:1-45

Leech G (1981) Style in fiction. Longman Group Ltd, London \& New York

Levine G (1996). Putting the 'literature' back into literature departments. ADE Bull 113:23-42.
Lincoln SY, Guba EG (1985) Naturalistic inquiry. Sage, Thousand Oaks

Mancing H (2015). Guzman de Alfarache and after: the Spanish Picaresque Novel in the seventeenth century. The Picaresque Novel in western literature: from the sixteenth century to the Neopicaresque. Cambridge University Press, pp. 40-59

Mao L (1991). Pragmatic universals and their implications. Unpublished PhD Dissertation, University of Minnesota

Mitchell T (1957) The language of buying and selling in Cyrenaica. Hesperis 44:31-71

McIntyre D (2012) Linguistics and literature: stylistics as a tool for the literary critic. SRC Working 1:1-11

Miller D (1981) Narrative and its discontents. Princeton University Press, Princeton

Mooney A, Peccel J, La Belle S (2011) The language, society and power. Routledge \& CRS Press

Myers R (1977) Towards a definition of irony. In: Fasold RalphW, Shuy Roger ed. Studies in language variation. Georgetown University Press, Washington, pp. 171-183

Neuendorf K (2002) The content analysis guidebook. Sage, Thousand Oaks

O'Halloran K (2007) Critical discourse analysis and the corpus-informed interpretation of metaphor at the register level. Appl Linguist 28/1:1-24

Orpin D (2005) Corpus linguistics and critical discourse analysis: examining the ideology of sleaze. Int J Corpus Linguist 10:1-27

Pateman C (1988) The sexual contract. Stanford University Press, Stanford

Paulson R (2000) The life of Henry Fielding. Blackwell Publishers, Oxford

Peck B (2011) Age-related differences in doctor-patient interaction and patient satisfaction, vol 5. Hindawi Publishing Corporation, pp. 42-52

Pittock M (2013) Material culture and sedition, 1688-1760. Palgrave Macmillan, New York

Polit D, Beck C (2012) Nursing research: principles and methods. Lippincott Williams \& Wilkins, Philadelphia

Pope R (2005) Creativity: theory, history, practice. Routledge, London

Rawson G (1959). Professor Empson's Tom Jones. In: Note and queries, pp. 400-404., ed. Donald C. Freeman, US.A Holt, Rinehart and Winston Inc

Richards J (1985) Longman dictionary of applied linguistics. Longman Group Ltd, Great Britain

Schreier M (2012) Qualitative content analysis in practice. Sage, Thousand Oaks, CA

Shanley M (2007) Marriage contract and social contract in seventeenth-century political thought. In: Nancy JHirschmann, McClure KirstieM ed. Feminist interpretation of John Locke. Pennsylvania State University, University Park

Short M (1986). Literature and language teaching and the nature of language, In: Theo D'heen (ed) Linguistics and the study of literature. Rodopi, Amsterdam

Simpson P, Mayar A, Statham S (2018). Language and power: a resource book for students. Routledge \& CRS Press

Slembrouk S (2003) What is meant by 'discourse analysis'? Routledge, London

Sperber D, Wilson D (1981) Irony and the use-mention distinction. In: Cole Peter ed. Radical pragmatics. Academic Press, New York, pp. 295-318

Stevenson J, Paulson R (2000) The life of Henry Fielding: a critical biography. Blackwell Publishers, Oxford

Stevenson J (2005) The real history of Tom Jones. Palgrave Macmillan, New York

Van Dijk T (1972). Some aspects of text grammar. Mouton, The Hague

Van Dijk T (2006) Discourse, context and cognition. Discourse Stud 8(1):159-177

Van Dijk T (2008a) Discourse and context: a sociocognitive approach. Cambridge University Press

Van Dijk T (2008b). Society and discourse: how context controls text and talk. Cambridge University Press

Van Dijk T (ed) (1985). Handbook of discourse analysis, vol 1: Discipline of discourse. Academic Press

Van Valin RD (2001). Functional linguistics. In: Aronoff M, Rees-Miller J (eds) The handbook of linguistics. Blackwell, Oxford, pp. 319-336

Wall C (2006) The prose of things: transformations of description in the eighteenth century. University of Chicago Press, Chicago

Wallace E (1997) Consuming subjects: women, shopping and business in the eighteenth century. Columbia University Press, New York

Werner J (1973) The interpolated narratives in the fiction of Fielding and Smollet: an epistemological view. Stud Novel 5:271-283

Wicks U (2002). The picaresque genre. In: LaBlanc ML (ed) Literature criticism from 1400 to 1800 , vol 78 . Gale

Williams JP (1984) Does mention (or pretense) exhaust the concept of irony? J Exp Psychol 113(1):127-129

\section{Acknowledgements}

This study has grown out of the context of the many conversations, discussions, arguments, and debates with many people engaged in literary theory, pragmatics, 
and sociolinguistics; these include professor Sadiq Gohar, Professor Sami Boudelaa, Dr. Emad El-dali and Mr. Mohammad Shahid.

\section{Competing interests}

The author declares no competing interests.

\section{Additional information}

Correspondence and requests for materials should be addressed to H.M.E-d.

Reprints and permission information is available at http://www.nature.com/reprints

Publisher's note Springer Nature remains neutral with regard to jurisdictional claims in published maps and institutional affiliations. (c) (i) Open Access This article is licensed under a Creative Commons Attribution 4.0 International License, which permits use, sharing, adaptation, distribution and reproduction in any medium or format, as long as you give appropriate credit to the original author(s) and the source, provide a link to the Creative Commons license, and indicate if changes were made. The images or other third party material in this article are included in the article's Creative Commons license, unless indicated otherwise in a credit line to the material. If material is not included in the article's Creative Commons license and your intended use is not permitted by statutory regulation or exceeds the permitted use, you will need to obtain permission directly from the copyright holder. To view a copy of this license, visit http://creativecommons.org/ licenses/by/4.0/.

(C) The Author(s) 2021 